\title{
Feeding by phototrophic red-tide dinoflagellates: five species newly revealed and six species previ- ously known to be mixotrophic
}

\author{
Hae Jin Jeong ${ }^{1, *}$, Yeong Du Yoo ${ }^{2}$, Jae Yeon Park ${ }^{3}$, Jae Yoon Song ${ }^{4}$, \\ Seong Taek Kim ${ }^{1}$, Seung Hyun Lee ${ }^{1}$, Kwang Young Kim ${ }^{5}$, Won Ho Yih ${ }^{6}$
}

${ }^{1}$ School of Earth and Environmental Sciences, College of Natural Sciences, Seoul National University, Seoul 151-747, Republic of Korea

${ }^{2}$ Saemankeum Environmental Research Center, Kunsan National University, Kunsan 573-701, Republic of Korea

${ }^{3}$ Research Institute of Oceanography \& Red Tide Research Center, Seoul National University, Seoul 151-747, Republic of Korea

${ }^{4}$ Department of Oceanography, Kunsan National University, Kunsan 573-701, Republic of Korea

${ }^{5}$ Faculty of Earth Systems and Environmental Sciences, College of Natural Sciences, Chonnam National University, Kwangju 500-757, Republic of Korea

${ }^{6}$ Coastal Research Center, Kunsan National University, Kunsan 573-701, Republic of Korea

\begin{abstract}
We report here for the first time that 5 red-tide dinoflagellates (Gymnodinium catenatum, G. impudicum, Lingulodinium polyedrum, Prorocentrum donghaiense, and P. triestinum) which had been previously thought to be exclusively autotrophic dinoflagellates are mixotrophic species. We investigated the feeding behaviors, the kinds of prey species that 11 mixotrophic red-tide dinoflagellates (Akashiwo sanguinea, Alexandrium tamarense, G. catenatum, G. impudicum, Heterocapsa triquetra, L. polyedrum, P. donghaiense, P. micans, P. minimum, P. triestinum, and Scrippsiella trochoidea) fed on, and the effects of the prey concentration on the growth and ingestion rates of $P$. donghaiense, $H$. triquetra, $P$. micans, and L. polyedrum when feeding on algal prey. We have also calculated grazing coefficients by combining field data on abundances of $P$. donghaiense, H. triquetra, P. micans, and $L$. polyedrum and co-occurring prey species. All algal predators tested in the present study ingested small phytoplankton species that had equivalent spherical diameters (ESDs) $<12 \mu \mathrm{m}$. A. sanguinea and $L$. polyedrum were able to ingest large phytoplankton species such as $H$. triquetra, $S$. trochoidea, and A. tamarense. Prorocentrum spp. fed on prey by engulfing the prey cell through body sutures, while $S$. trochoidea engulfed prey through the apical horn as well as through the sulcus. Specific growth rates of $P$. donghaiense, $H$. triquetra, and $P$. micans on a cryptophyte and $L$. polyedrum on $P$. minimum and $S$. trochoidea increased with increasing mean prey concentration, with saturation occurring at mean prey concentrations of 110 to $480 \mathrm{ng} \mathrm{C} \mathrm{ml}^{-1}$. The maximum specific growth rates (mixotrophic growth) of $P$. donghaiense, $H$. triquetra, and P. micans on the cryptophyte were 0.510, 0.283 , and $0.197 \mathrm{~d}^{-1}$, respectively, under a $14: 10 \mathrm{~h}$ light:dark cycle of $20 \mu \mathrm{E} \mathrm{m}^{-2} \mathrm{~s}^{-1}$, while their growth rates (phototrophic growth) under the same light conditions without added prey were $0.375,0.184$, and $0.106 \mathrm{~d}^{-1}$, respectively. The maximum specific growth rates of $L$. polyedrum on $P$. minimum and $S$. trochoidea were 0.254 and $0.303 \mathrm{~d}^{-1}$, respectively, under a $14: 10 \mathrm{~h}$ light:dark cycle of $50 \mu \mathrm{E} \mathrm{m} \mathrm{m}^{-2} \mathrm{~s}^{-1}$, while their growth rates without added prey were 0.157 and $0.182 \mathrm{~d}^{-1}$, respectively. Maximum ingestion rates of $P$. donghaiense, $H$. triquetra, and $P$. micans on the cryptophyte were much lower than those of $L$. polyedrum on $S$. trochoidea and P. minimum. The calculated grazing coefficients of P. donghaiense, $H$. triquetra, and P. micans on the cryptophyte were up to $2.67,0.091$, and $0.041 \mathrm{~h}^{-1}$, respectively, while those of $L$. polyedrum on small Prorocentrum spp. and $S$. trochoidea were up to 0.026 and $0.011 \mathrm{~h}^{-1}$, respectively. The results of the present study suggest that the algal predators sometimes have a potentially considerable grazing impact on populations of the algal prey.
\end{abstract}

KEY WORDS: Feeding process $\cdot$ Harmful algal bloom $\cdot$ Ingestion $\cdot$ Marine $\cdot$ Protist $\cdot$ Red tide 


\section{INTRODUCTION}

Recently, several red-tide dinoflagellates which had previously been thought to be exclusively autotrophic dinoflagellates have been found to be mixotrophic dinoflagellates (i.e. capable of both photosynthesis and ingesting prey) (Bockstahler \& Coats 1993, Chang \& Carpenter 1994, Jacobson \& Anderson 1996, Granéli et al. 1997, Stoecker et al. 1997, Smalley et al. 1999, Stoecker 1999, Skovgaard 2000, Jeong et al. 2004, 2005). If a red-tide dinoflagellate thought to be an autotrophic dinoflagellate is revealed to be mixotrophic, studies on the ecology, physiology, and biochemistry of that red-tide dinoflagellate should be conducted, taking into consideration the mixotrophic property of the dinoflagellate and also the models for predicting the outbreak, persistence, and decline of red tides dominated by the red-tide dinoflagellate, and the related management strategies should be adjusted to reflect these facts. However, mixotrophy in many red-tide dinoflagellate species have been not explored yet, even though these dinoflagellates have formed huge red tides which have sometimes caused largescale mortalities of fin-fish and shellfish and thus great losses to the aquaculture and tourist industries of many countries (ECOHAB 1995).

Recently, we found food vacuoles inside 5 red-tide dinoflagellates (Prorocentrum donghaiense, P. triestinum, Gymnodinium catenatum, G. impudicum, and Lingulodinium polyedrum) which had previously been known as autotrophic dinoflagellates. P. donghaiense (previously $P$. dentatum in Korean, Chinese and Japanese waters, and in some USA waters, Qi \& Wang 2003; reported maximum concentrations = 360000 cells $\mathrm{ml}^{-1}$, Lu et al. 2002) has often formed huge red tide patches in Korean, Chinese, and Japanese waters (Yanagi et al. 1994, NFRDI 1998, Liu \& Wang 2002). P. triestinum has often formed huge red tide patches in the waters off many countries (Hernandez-Becerril et al. 2000, Labib 2000, Lu \& Hodgkiss 2004). G. catenatum, known as a toxic species, has caused fish kills and/or paralytic shellfish poisoning in many areas (Anderson et al. 1989, Hallegraeff \& Fraga 1998, McMinn et al. 2001, Glibert et al. 2002). G. impudicum has also sometimes caused fish kills (Glibert et al. 2002). L. polyedrum (previously Gonyaulax polyedra; reported maximum concentrations $=25000$ cells $\mathrm{ml}^{-1}$, Marasović 1989; 22200 cells ml$^{-1}$, Sweeney 1975) has caused red tides in the coastal waters off many countries (Holmes et al. 1967, Sweeney 1975, Marasović 1989, Bruno et al. 1990, Legović et al. 1991, Altamirano et al. 1996, Zhu et al. 1997, Kudela \& Cochlan 2000, Bennouna et al. 2002). In particular, $L$. polyedrum is one of the most common causative species of red tides off southern California, USA (Eppley
\& Harrison 1975, Morey-Gaines 1980, Jeong 1995, Kudela \& Cochlan 2000), and is one of the most studied red-tide organisms to date (reviewed by Lewis \& Hallett 1997). There have been some studies on the possible uptake of amino acids and $\mathrm{B}_{12}$ (Carlucci 1970, Gaines \& Elbrächter 1987, Nakamura et al. 1993), but there has been no report on the phagotrophy of $L$. polyedrum yet. There have been a large number of studies on the cell chemistry, bioluminescence, life cycle, physiology, ecology, and/or the cysts of these dinoflagellates; however, most studies have been conducted under the assumption that these dinoflagellates are autotrophic dinoflagellates. Therefore, whether these dinoflagellates are exclusively autotrophic or mixotrophic should be tested.

The red-tide dinoflagellates Akashiwo sanguinea, Alexandrium tamarense, Heterocapsa triquetra, Prorocentrum micans, P. minimum, and Scrippsiella trochoidea were previously thought to be mixotrophic dinoflagellates (Bockstahler \& Coats 1993, Nygaard \& Tobiesen 1993, Jacobson \& Anderson 1996, Legrand et al. 1998). A. sanguinea has been known to feed on small ciliates (Bockstahler \& Coats 1993) and A. tamarense on bacteria (Nygaard \& Tobiesen 1993), but whether these dinoflagellates are able to feed on cooccurring phytoplankton prey has not been tested yet. P. minimum has been known to feed on cryptophytes (Stoecker et al. 1997). Legrand et al. (1998) reported that when the cyanobacteria Synechococcus spp., the diatom Thalassiosira pseudonana, and a small unidentified autotrophic flagellate were provided as prey, the small flagellate and the diatom were sometimes observed inside $H$. triquetra, in contrast to the cyanobacterium which was never observed inside this dinoflagellate. Jacobson \& Anderson (1996) reported that $P$. micans and $S$. trochoidea were mixotrophic because food vacuoles were observed inside the predators. However, there have been few reports on the feeding behaviors and the kinds of prey species that these red-tide dinoflagellates feed on when diverse phytoplankton species are provided as prey.

The mixotrophic red-tide dinoflagellate Gonyaulax polygramma has been known to feed on phytoplankton cells by engulfing the prey through both the apical horn and the sulcus (Jeong et al. 2005), while other engulfment-feeding mixotrophic and heterotrophic dinoflagellates have only been known to engulf a prey cell through the sulcus (Schnept \& Elbrächter 1992, Skovgaard 1996, Jeong et al. 1997, 1999, Hansen \& Calado 1999). Two interesting questions arise in the case of engulfment-feeding mixotrophic dinoflagellates. (1) Is there any other dinoflagellate that engulfs the prey through both the apical horn and the sulcus like $G$, polygramma? (2) Are there any further feeding behaviors other than that of 
engulfing the prey through the apical horn and/or the sulcus? The feeding behaviors of Prorocentrum spp., which are not known as yet, are of interest because they have no apical horn or sulcus. The periflagellar area and the suture between 2 valves, which are the only openings for Prorocentrum spp., could be candidates for the feeding sites.

Exploring the kinds of prey species that red-tide dinoflagellates feed on is important from an ecological perspective for the following reasons: (1) based on the results of these experiments, we can judge whether each red-tide dinoflagellate is a potential predator, prey, or competitor of other phytoplankton prey for nutrients. The results of this study may reveal predator-prey relationships among phototrophic organisms so far unknown. (2) If the red-tide dinoflagellates and newly discovered prey species co-occur, we should consider the competition between red-tide dinoflagellates and co-occurring heterotrophic protists and/or metazooplankton on the common algal prey species. We must also consider the possibility that in situ grazing impacts by microzooplankton on the algal prey have been overestimated because red-tide dinoflagellates may significantly reduce the populations of cooccurring algal prey. (3) The predation of the algal predator on the algal prey can be a driving force for the succession of the dominant species during red tides in series if the algal predator has a great grazing impact on the populations of the algal prey and if the algal prey supports the growth of the algal predators. The results of these experiments may provide ideas for testing algal predation as a potential mechanism for succession of the dominant species during serial red tides.

We established monoclonal cultures of 11 red-tide dinoflagellates (Akashiwo sanguinea, Alexandrium tamarense, Gymnodinium catenatum, G. impudicum, Heterocapsa triquetra, Lingulodinium polyedrum, Prorocentrum donghaiense, $P$. micans, $P$. minimum, $P$. triestinum, and Scrippsiella trochoidea) and observed the feeding behavior and determined the prey species therein. We conducted experiments to determine the effects of prey concentration on the growth and ingestion rates of $P$. donghaiense, $H$. triquetra, and $P$. micans on an unidentified cryptophyte species (equivalent spherical diameter, $\mathrm{ESD}=5.6 \mu \mathrm{m}$ ) and $L$. polyedrum when feeding on unialgal diets of $P$. minimum and $S$. trochoidea. We also estimated grazing coefficients attributable to $P$. donghaiense, $H$. triquetra, and $P$. micans on co-occurring cryptophytes and $L$. polyedrum on co-occurring small Prorocentrum spp. and $S$. trochoidea using our data for ingestion rates obtained from the laboratory experiments and the abundances of predator and prey in the field. The results of the present study provide a basis for understanding the feed- ing behaviors of mixotrophic red-tide dinoflagellates, the interactions among the red-tide dinoflagellates and between the red-tide dinoflagellates and co-occurring phytoplankton belonging to other classes, and the dynamics of red tides dominated by red-tide dinoflagellates.

\section{MATERIALS AND METHODS}

Preparation of experimental organisms. Phytoplankton species were grown at $20^{\circ} \mathrm{C}$ in enriched $\mathrm{f} / 2$ seawater media (Guillard \& Ryther 1962) without silicate, under continuous illumination of $50 \mu \mathrm{E} \mathrm{m} \mathrm{m}^{-2} \mathrm{~s}^{-1}$ provided by cool white fluorescent lights (Table 1). The mean ESD $( \pm$ SD) was measured using an electronic particle counter (Coulter Multisizer II, Coulter Corporation).

We conducted experiments to determine the effects of prey concentration on the growth and ingestion rates of Heterocapsa triquetra, Prorocentrum donghaiense, P. micans, and Lingulodinium polyedrum when feeding on unialgal diets of algal prey. For the isolation and culture of $H$. triquetra (HTMS0402), plankton samples collected with a $40 \mathrm{~cm}$ diameter, $25 \mu \mathrm{m}$ mesh plankton net were taken from the waters

Table 1. Taxa, sizes, and concentration of phytoplankton species offered as food to algal predators in Expts 1 and 2. The taxa whose initial prey concentrations were not provided were used for predators only. Mean equivalent spherical diameter $(E S D, \mu m) \pm S D$ was measured before the start of the experiments. $\mathrm{n}>2000$ for each species. ${ }^{*}$ PRY: Prymnesiophyceae; CRP: Cryptophyceae; RAP: Raphidophyceae; DIN: Dinophyceae. The densities of algal predators were 4000 to 5500 cells $\mathrm{ml}^{-1}$ ( $P$. donghaiense, $P$. minimum, and P. triestinum) and 1000 to 1500 cells ml ${ }^{-1}$ (others)

\begin{tabular}{|llc|}
\hline Species & $\begin{array}{l}\text { ESD } \\
( \pm \text { SD) }\end{array}$ & $\begin{array}{c}\text { Initial prey } \\
\text { conc. } \\
\text { (cells ml }^{-1} \text { ) }\end{array}$ \\
\hline Isochrysis galbana ( ${ }^{*}$ PRY) & $5.2(1.0)$ & 200000 \\
Unidentified cryptophyte (CRP) & $5.6(1.5)$ & 100000 \\
Amphidinium carterae (DIN) & $6.6(1.8)$ & 55000 \\
Rhodomonas salina (CRP) & $7.0(2.0)$ & 30000 \\
Heterosigma akashiwo (RAP) & $11.5(1.9)$ & 20000 \\
Prorocentrum minimum (DIN) & $12.1(2.5)$ & 13000 \\
Prorocentrum triestinum (DIN) & $12.6(2.0)$ & 13000 \\
Prorocentrum donghaiense (DIN) & $13.3(2.0)$ & 13000 \\
Heterocapsa triquetra (DIN) & $15.0(4.3)$ & 13000 \\
Gymnodinium impudicum (DIN) & $17.8(2.6)$ & \\
Scrippsiella trochoidea (DIN) & $22.8(2.7)$ & $5000-6000$ \\
Cochlodinium polykrikoides (DIN) & $25.9(2.9)$ & $3000-5000$ \\
Prorocentrum micans (DIN) & $26.6(2.8)$ & $3000-5000$ \\
Alexandrium tamarense (DIN) & $28.1(3.1)$ & $3000-4000$ \\
Akashiwo sanguinea (DIN) & $30.8(3.5)$ & $1000-3000$ \\
Gymnodinium catenatum (DIN) & $33.9(1.6)$ & $1000-3000$ \\
Lingulodinium polyedrum (DIN) & $38.2(3.6)$ & \\
\hline
\end{tabular}


of Masan Bay, Korea, during February 2004, when the water temperature and salinity were $7.5^{\circ} \mathrm{C}$ and 30.5 psu, respectively. The samples were screened gently through a $154 \mu \mathrm{m}$ Nitex mesh and placed in 11 polycarbonate (PC) bottles. Fifty $\mathrm{ml}$ of $\mathrm{f} / 2$ media was added as food. The bottles were placed on shelves and incubated at $20^{\circ} \mathrm{C}$ under continuous illumination of $50 \mu \mathrm{E} \mathrm{m} \mathrm{m}^{-2} \mathrm{~s}^{-1}$ of cool white fluorescent light. After $3 \mathrm{~d}$, aliquots of the enriched water were transferred to 6 -well tissue culture plates and a monoclonal culture was established by 2 serial single-cell isolations. Once dense cultures of $H$. triquetra were obtained, they were transferred to $21 \mathrm{PC}$ bottles containing ca. $500 \mathrm{ml}$ of fresh $\mathrm{f} / 2$ seawater media (final culture volume $=\mathrm{ca}$. 1 l) every $2 \mathrm{wk}$. Approximately 1 mo before the feeding experiments were conducted, the bottles containing $H$. triquetra were incubated under a 14:10 h light:dark cycle of $20 \mu \mathrm{E} \mathrm{m}^{-2} \mathrm{~s}^{-1}$ of cool white fluorescent light.

For the isolation and culture of Prorocentrum donghaiense (PDHMS0206), plankton samples collected with a clean bucket were taken from the coastal waters off Masan, during June 2002, when the water temperature and salinity were $22.6^{\circ} \mathrm{C}$ and $27.5 \mathrm{psu}$, respectively. The samples were screened and placed in $11 \mathrm{PC}$ bottles to which $50 \mathrm{ml}$ of $\mathrm{f} / 2$ nutrient medium was added. The bottles were placed on plankton wheels rotating at $0.9 \mathrm{rpm}$ and incubated at $20^{\circ} \mathrm{C}$

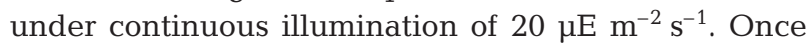
dense cultures of $P$. donghaiense were obtained, they were transferred every $2 \mathrm{wk}$ to $21 \mathrm{PC}$ bottles of fresh $\mathrm{f} / 2$ seawater medium.

For the isolation and culture of Prorocentrum micans (PMCJH99), plankton samples collected with a clean bucket were taken from the coastal waters off Jinhae, Korea, during June 1999, when the water temperature and salinity were $21.3^{\circ} \mathrm{C}$ and $27.7 \mathrm{psu}$, respectively. Fifty $\mathrm{ml}$ of $\mathrm{f} / 2$ media was added as food. The bottles were placed on shelves and incubated at $20^{\circ} \mathrm{C}$ under continuous illumination of $50 \mu \mathrm{E} \mathrm{m} \mathrm{m}^{-2} \mathrm{~s}^{-1}$ of cool white fluorescent light. Approximately 1 mo before the feeding experiments were conducted, the bottles containing $P$. micans were incubated under a $14: 10 \mathrm{~h}$ light:dark cycle of $20 \mu \mathrm{E} \mathrm{m} \mathrm{m}^{-2} \mathrm{~s}^{-1}$ of cool white fluorescent light.

A culture of Lingulodinium polyedrum (LpSIO95), originating from Scripps Institution of Oceanography, University of California, San Diego, USA (Jeong \& Latz 1994), has been maintained in our laboratory since 1995. Dense cultures of $L$. polyedrum incubated at $20^{\circ} \mathrm{C}$ under continuous illumination of $50 \mu \mathrm{E} \mathrm{m} \mathrm{m}^{-2} \mathrm{~s}^{-1}$ were transferred to $21 \mathrm{PC}$ bottles containing ca. $500 \mathrm{ml}$ of fresh $\mathrm{f} / 2$ seawater media (final culture volume = ca. 1 l) every $2 \mathrm{wk}$. Approximately 1 mo before the feeding experiments were conducted, the bottles containing $L$. polyedrum were incubated under a 14:10 h light:dark cycle of $50 \mu \mathrm{E} \mathrm{m} \mathrm{m}^{-2} \mathrm{~s}^{-1}$ of cool white fluorescent light. L. polyedrum became unhealthy under a $14: 10 \mathrm{~h}$ light:dark cycle of $20 \mu \mathrm{E} \mathrm{m} \mathrm{m}^{-2} \mathrm{~s}^{-1}$.

Prey species. Expt 1 was designed to investigate whether or not an algal predator was able to feed on each target phytoplankton species when unialgal diets of diverse phytoplankton species were provided (Table 1). The initial concentrations of each phytoplankton species offered were similar in terms of their carbon biomass. To confirm no ingestion by the algal predator on some phytoplankton species, additional higher prey concentrations were provided.

A dense culture of an algal predator maintained in f/2 media and growing photosynthetically in an exponential growth phase was transferred to a 11 PC bottle containing freshly filtered seawater. Three $1 \mathrm{ml}$ aliquots were then removed from the bottle and examined using a compound microscope to determine the algal predator's concentration.

In this experiment, the initial concentrations of an algal predator and each target phytoplankton species were established using an autopipette to deliver a predetermined volume of culture with a known cell density to the experimental bottles. Triplicate $80 \mathrm{ml}$ PC bottles (mixtures of the algal predator and phytoplankton) and triplicate predator control bottles (containing the algal predator only) were set up for each target phytoplankton species. The bottles were filled to capacity with freshly filtered seawater, capped, and then placed on a vertically rotating plate rotating at $0.9 \mathrm{rpm}$ and incubated at $20^{\circ} \mathrm{C}$ under continuous illumination of $20 \mu \mathrm{E} \mathrm{m} \mathrm{m}^{-2} \mathrm{~s}^{-1}$ (but $50 \mu \mathrm{E} \mathrm{m} \mathrm{m}^{-2} \mathrm{~s}^{-1}$ for Lingulodinium polyedrum because this species became unhealthy under a 14:10 h light:dark cycle of $20 \mu \mathrm{E} \mathrm{m}^{-2} \mathrm{~s}^{-1}$ ) of cool white fluorescent light. After $6 \mathrm{~h}$ incubation, a $5 \mathrm{ml}$ aliquot was removed from each bottle and transferred into a $10 \mathrm{ml}$ bottle. Aliquots $(0.2 \mathrm{ml})$ were placed on slides and then cover-glasses were added. Under these conditions, the algal predator cells were alive, but almost motionless. The protoplasms of more than 100 algal predator cells were carefully examined with a compound microscope and/or an epifluorescent microscope at a magnification of 100 to $400 \times$ to determine whether or not the algal predator was able to feed on the target prey species. Pictures of the algal predator at several different stages of the feeding process were taken using an Olympus camera on a compound microscope at a magnification of 100 to $400 \times$.

Feeding behaviors. Expt 2 was designed to investigate the feeding mechanisms of 11 red-tide dinoflagellates on a cryptophyte (Amphidinium carterae, Heterosigma akashiwo, P. minimum, H. triquetra, $S$. trochoidea, and/or A. tamarense). The initial concentrations of predator and prey were the same as in Expt 1. 
The initial concentrations of an algal predator and its target phytoplankton species were established using an autopipette to deliver a predetermined volume of culture with a known cell density to the experimental bottles. One $80 \mathrm{ml} \mathrm{PC}$ bottle (mixtures of the algal predator and phytoplankton) was set up for each target phytoplankton species. The bottle was filled to capacity with freshly filtered seawater, capped, and then well mixed. After $1 \mathrm{~min}$ incubation, a $1 \mathrm{ml}$ aliquot was removed from the bottle and transferred into a $1 \mathrm{ml}$ Sedgwick-Rafter chamber. By monitoring the behavior of more than 30 unfed algal predator cells for each target phytoplankton under a compound microscope at a magnification of $100 \times$, the feeding behaviors were determined. In addition, a $0.1 \mathrm{ml}$ aliquot was removed from the bottle and placed on slides and then coverglasses were added. A series of pictures showing the feeding process of the algal predator cell were taken using a digital camera on a compound microscope at a magnification of 100 to $400 \times$.

The behavior of 112 unfed Prorocentrum micans cells when fed the cryptophyte was monitored using a compound microscope $(400 \times)$. Frequencies of $P$. micans engulfing prey cells through sutures on the anterior and posterior ends, on the lower-right and the lower-left parts of the right valve were obtained.

Additional experiments to determine the time for an algal prey cell to be completely engulfed by an algal predator after the prey cell was contacted by the predator (i.e. handling time) were set up in the same way as Expt 2. After $1 \mathrm{~min}$ incubation, a $1 \mathrm{ml}$ aliquot was removed from the bottle and transferred into a $1 \mathrm{ml}$ Sedgwick-Rafter chamber. The time for a cryptophyte cell $(\mathrm{ESD}=5.6 \mu \mathrm{m})$ to be completely engulfed by Prorocentrum donghaiense, Heterocapsa triquetra, and P. micans after the prey cell was contacted by the predator was measured by tracking 5 unfed $P$. donghaiense, 6 unfed $H$. triquetra cells, and 5 unfed $P$. micans cells under a compound microscope at a magnification of 100 to $400 \times$. In addition, by monitoring the behavior of 5 to 7 unfed Lingulodinium polyedrum cells for each prey species, the time for a cryptophyte, Heterosigma akashiwo, $P$. minimum, and Scrippsiella trochoidea cell to be completely engulfed by L. polyedrum was measured.
Effects of the prey concentration. Expt 3 was designed to investigate the effects of prey concentration on the growth and ingestion rate of Prorocentrum donghaiense, Heterocapsa triquetra, P. micans, and Lingulodinium polyedrum (Table 2). We measured the growth, ingestion, and clearance rates of $P$. donghaiense, $H$. triquetra, and $P$. micans on a cryptophyte species (carbon content per cell $=0.017 \mathrm{ng} \mathrm{C}$, Strathmann 1967) and those of L. polyedrum on unialgal diets of $P$. minimum PminUSA (carbon content per cell $=0.13 \mathrm{ng}$ C) and Scrippsiella trochoidea STKP9909 (0.67 ng C) as a function of prey concentration.

A dense culture of an algal predator, maintained in f/2 medium and growing photosynthetically under a

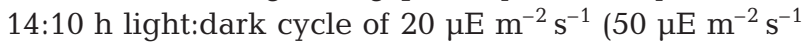
for Lingulodinium polyedrum) for approximately $1 \mathrm{mo}$, was transferred into a $1 \mathrm{l} \mathrm{PC}$ bottle. Three $1 \mathrm{ml}$ aliquots from the bottle were counted using a compound microscope to determine the cell concentrations of the algal predator, and the cultures were then used to conduct experiments.

The initial concentrations of an algal predator and each target phytoplankton species were established using an autopipette to deliver predetermined volumes of known cell concentrations to the bottles. Triplicate $80 \mathrm{ml}$ PC experimental bottles (containing mixtures of predator and prey) and triplicate prey control bottles (containing prey only) were set up for each predator-prey combination. Triplicate predator control bottles (containing the predator only) were also established at 1 predator concentration. A f/2 medium (36 ml) was added to all bottles, which were then filled to capacity with freshly filtered seawater and capped. Here, we added only $36 \mathrm{ml}$ so as to add the same amount of $\mathrm{f} / 2$ medium to all bottles, because in the bottles containing the highest prey concentrations, a volume of only approximately $40 \mathrm{ml}$ remained after adding the prey and predator. To determine the actual initial predator and prey densities (cells $\mathrm{ml}^{-1}$ ) at the beginning of the experiment and after 24,48, and $72 \mathrm{~h}$ incubation, $6 \mathrm{ml}$ aliquots were removed from each bottle and fixed with $5 \%$ Lugol's solution, and all algal predator cells and all

Table 2. Design of Expt 3. Values in prey and predator columns represent the actual initial concentrations (density columns, cells ml ${ }^{-1}$ )

\begin{tabular}{lcclc|}
\hline \multicolumn{1}{c}{ Species } & & & Prey & Density \\
\cline { 5 - 5 } Prorocentrum donghaiense & Density & & Species & \\
Heterocapsa triquetra & $5-2763$ & & Cryptophyte & $0,46,167,691,1686,6130,12254,27448$ \\
P. micans & $21-2268$ & & Cryptophyte & $0,53,160,656,1689,4709,11291$ \\
Lingulodinium polyedrum & $8-3790$ & & Cryptophyte & $0,65,214,939,2638,7353,16917,32513$, \\
L. polyedrum & $5-1243$ & & Prorocentrum minimum & $0,18,47,95,268,804,1796,5059,8475$ \\
& $6-605$ & & Scrippsiella trochoidea & $0,9,20,36,151,624,1783$ \\
\hline
\end{tabular}


or $>300$ prey cells in three $1 \mathrm{ml}$ Sedgwick-Rafter counting chambers were enumerated. Prior to taking subsamples, the condition of the algal predator and its prey was assessed under a dissecting microscope. The bottles were filled again to capacity with $f / 2$ medium, capped, placed on a vertically rotating plate at $0.9 \mathrm{rpm}$, and incubated at $20^{\circ} \mathrm{C}$ under a $14: 10 \mathrm{~h}$ light:dark cycle of $20 \mu \mathrm{E} \mathrm{m} \mathrm{m}^{-2} \mathrm{~s}^{-1}\left(50 \mu \mathrm{E} \mathrm{m} \mathrm{m}^{-2} \mathrm{~s}^{-1}\right.$ for Lingulodinium polyedrum) of cool white fluorescent light. The dilution of the cultures associated with refilling the bottles was taken into consideration in calculating growth and ingestion rates.

The specific growth rate of an algal predator $\left(\mu, \mathrm{d}^{-1}\right)$, was calculated by averaging the instantaneous growth rates (IGR) for each sampling interval, calculated as:

$$
\operatorname{IGR}=\frac{\operatorname{In}\left(S_{t_{2}} / S_{t_{1}}\right)}{t_{2}-t_{1}}
$$

where $S_{t_{1}}$ and $S_{t_{2}}$ are the concentration of the algal predator at consecutive samplings. The final sampling time $\left(t_{2}\right)$ for the calculation was $48 \mathrm{~h}$. In some experimental bottles (i.e. containing high prey concentrations), increases in the growth rates of the algal predator at 48 to $72 \mathrm{~h}$ incubation were depressed. Mean prey concentrations for $48 \mathrm{~h}$ were also calculated by averaging the instantaneous mean prey concentrations at 0 to 24 and 24 to $48 \mathrm{~h}$. The instantaneous mean prey concentration for each sampling interval was calculated using the equations of Frost (1972). The prey concentrations after subsampling were lower than those before subsampling due to the dilution of the cultures associated with refilling the bottles and thus the prey concentrations before and after subsampling were dependent. Therefore, we calculated the specific growth rate of the algal predator by averaging the IGR for each sampling interval rather than by plotting prey concentrations over sampling times.

Data for the algal predator's growth rate were fitted to a Michaelis-Menten equation:

$$
\mu=\frac{\mu_{\max }\left(x-x^{\prime}\right)}{K_{\mathrm{GR}}+\left(x-x^{\prime}\right)}
$$

where $\mu_{\max }$ is the maximum growth rate $\left(\mathrm{d}^{-1}\right)_{;} \mathrm{x}$ is prey concentration (cells $\mathrm{ml}^{-1}$ or $\mathrm{ng} \mathrm{C} \mathrm{ml}^{-1}$ ); $x^{\prime}=$ threshold prey concentration (where $\mu=0$ ); and $K_{\mathrm{GR}}$ is the prey concentration sustaining $1 / 2 \mu_{\max }$. Data were iteratively fitted to the model using Delta Graph $^{\circledR}$ (SPSS).

Ingestion and clearance rates for $48 \mathrm{~h}$ were also calculated using the equations of Frost (1972) and Heinbokel (1978). The incubation time for calculating ingestion and clearance rates was the same as for estimating the growth rate. Ingestion rate (IR) data were fitted to a Michaelis-Menten equation:

$$
\mathrm{IR}=\frac{I_{\max }}{K_{\mathrm{IR}}+(x)}
$$

where $I_{\max }$ is the maximum ingestion rate (cells predator ${ }^{-1} \mathrm{~d}^{-1}$ or ng $\mathrm{C}$ predator $\left.{ }^{-1} \mathrm{~d}^{-1}\right) ; x$ is prey concentration (cells ml ${ }^{-1}$ or $\mathrm{ng} \mathrm{C} \mathrm{ml} l^{-1}$ ); and $K_{\mathrm{IR}}$ is the prey concentration sustaining $1 / 2 I_{\max }$.

Potential grazing impact. We estimated the grazing coefficients attributable to Prorocentrum donghaiense, Heterocapsa triquetra, and P. micans on cryptophytes and attributable to Lingulodinium polyedrum on small Prorocentrum spp. and Scrippsiella trochoidea by combining field data on abundances of the grazers and the target prey with ingestion rates of the grazers on the prey obtained in the present study. Data on the abundances of $H$. triquetra and co-occurring cryptophytes used in this estimate were obtained from the water samples taken in Masan Bay, Korea (in 2003 to 2004). Data on the abundances of $P$. donghaiense and co-occurring cryptophytes used in this estimation were obtained from the water samples off Kohung (in 1998 to 1999), Kwangyang (in 1999 to 2003), Tongyoung (in 1998 to 2003), and Masan (in 2003), Korea. Data on the abundances of $P$. micans and co-occurring cryptophytes used in this estimate were obtained from water samples off Kohung (in 1998), Tongyoung (in 2003), and Masan (in 2003), Korea. Data on the abundances of $L$. polyedrum and co-occurring small Prorocentrum spp. (P. minimum + P. triestinum) used in this estimate were obtained from water samples taken off Kohung (in 1999) and Saemankeum (in 1999), Korea, and in the Krka Estuary, Croatia (east Adriatic coast) (Legović et al. 1991). Data on the abundances of $L$. polyedrum and co-occurring $S$. trochoidea used in this estimate were obtained from waters in the Los Angeles-Long Beach harbor, California, USA (Morey-Gaines 1980), and Kohung (in 2001) and Saemankeum (in 1999), Korea.

The grazing coefficients $\left(g, \mathrm{~h}^{-1}\right)$ were calculated as:

$$
g=\mathrm{CR} \times \mathrm{GC}
$$

where CR $\left(\mathrm{ml}\right.$ grazer $\left.^{-1} \mathrm{~h}^{-1}\right)$ is clearance rate of an algal predator on a target prey at a certain prey concentration and GC is grazer concentration (cells ml-1). CRs were calculated as:

$$
\mathrm{CR}=\mathrm{IR} / x
$$

where IR (cells eaten grazer ${ }^{-1} \mathrm{~h}^{-1}$ ) is the ingestion rate of the algal predator on the target prey and $x$ (cells $\mathrm{ml}^{-1}$ ) is prey concentration. CRs were corrected using $Q_{10}=2.8$ (Hansen et al. 1997) because in situ water temperatures and the temperature used in the laboratory for this experiment $\left(20^{\circ} \mathrm{C}\right)$ were sometimes different. 


\section{RESULTS}

\section{Prey species}

Among the phytoplankton prey offered, all algal predators tested in the present study (Akashiwo sanguinea, Alexandrium tamarense, Gymnodinium catenatum, G. impudicum, Heterocapsa triquetra, Lingulodinium polyedrum, Prorocentrum donghaiense, $P$. micans, $P$. triestinum, and Scrippsiella trochoidea) ingested the small phytoplankton species (the prymnesiophyte Isochrysis galbana, an unidentified cryptophyte, the dinoflagellate Amphidinium carterae, the cryptophyte Rhodomonas salina, and the raphidophyte Heterosigma akashiwo) which had ESDs < $12 \mu \mathrm{m}$ (Table 3, Fig. 1).

Alexandrium tamarense, Gymnodinium catenatum, Heterocapsa triquetra, Prorocentrum donghaiense, $P$. triestinum, and Scrippsiella trochoidea were able to feed on $P$. minimum which had an ESD of $12.1 \mu \mathrm{m}$, but they were not able to ingest the larger prey species (Table 3). $P$. micans was able to ingest $H$. triquetra which had an ESD of $15 \mu \mathrm{m}$, but it did not feed on the larger prey species. Akashiwo sanguinea and Lingulodinium polyedrum were able to ingest $H$. triquetra, S. trochoidea, and A. tamarense, but they did not feed on Cochlodinium polykrikoides, Gymnodinium catenatum or $P$. micans.

\section{Feeding behaviors}

The predators Prorocentrum spp. fed on prey by engulfing the prey cell through the sutures on the side of several parts of their bodies (Figs. $2 \& 3$ ). The frequencies of engulfing cryptophyte cells (n = 112) of $P$. micans through the suture at the anterior end, the posterior end, the side of the upper-right part, the upper-left part, the lower-right part, and the lowerleft part when viewed from the right valve were $25,20,20,19,11$, and $6 \%$, respectively. Up to 4 cryptophyte cells were observed to be simultaneously or consequently engulfed by a $P$. micans cell (Fig. 3M,N).

Scrippsiella trochoidea fed on phytoplankton cells by engulfing the prey through both the apical horn and the sulcus. S. trochoidea fed on small phytoplankton cells (Isochrysis galbana and an unidentified cryptophyte) by engulfing the prey through the apical horn, while it fed on large phytoplankton cells
(Rhodomonas salina, Amphidinium carterae, Heterosigma akashiwo, and Prorocentrum minimum) through the sulcus. However, Akashiwo sanguinea, Alexandrium tamarense, Gymnodinium catenatum, G. impudicum, Heterocapsa triquetra, and Lingulodinium polyedrum fed on phytoplankton cells by engulfing the prey only through the sulcus. A tow filament to anchor the prey cell was not observed for these algal predators.

The time (mean $\pm \mathrm{SE}$ ) for an unidentified cryptophyte cell $(\mathrm{ESD}=5.6 \mu \mathrm{m})$ to be completely engulfed by Lingulodinium polyedrum after the prey cell was contacted by the predator $(73 \pm 8 \mathrm{~s}, \mathrm{n}=5)$ was much shorter than that by Prorocentrum donghaiense (357 \pm $43 \mathrm{~s}, \mathrm{n}=5)$, Heterocapsa triquetra $(549 \pm 30 \mathrm{~s}, \mathrm{n}=6)$, or $P$. micans $(629 \pm 84 \mathrm{~s}, \mathrm{n}=5)$. The mean times $( \pm \mathrm{SE})$ for a cryptophyte, Heterosigma akashiwo, P. minimum, and Scrippsiella trochoidea cell to be completely engulfed by $L$. polyedrum after the prey cell was contacted by the predator, 73 (8) s, 178 (18) s, 293 (41) s, and 756 (81) s, respectively, increased with increasing prey size (Fig. 4).

\section{Effects of prey concentration}

With increasing mean prey concentration the specific growth rates of Prorocentrum donghaiense, Heterocapsa triquetra, and $P$. micans on a cryptophyte $(\mathrm{ESD}=5.6 \mu \mathrm{m})$ increased, with saturation at mean prey concentrations
Table 3. Feeding occurrences by algal predators on the phytoplankton species in Expts 1 and 2. Y: an algal predator was observed to contain food cells in the protoplasm; N: the algal predator was observed not to contain food cells. Pd: Prorocentrum donghaiense; Pt: P. triestinum; Pmin: P. minimum; Ht: Heterocapsa triquetra; Gi: Gymnodinium impudicum; St: Scrippsiella trochoidea; Pmic: P. micans; At: Alexandrium tamarense; As: Akashiwo sanguinea; Gc: Gymnodinium catenatum; Lp: Lingulodinium polyedrum

\begin{tabular}{|c|c|c|c|c|c|c|c|c|c|c|c|}
\hline Species & Pmin & $\mathrm{Pt}$ & $\mathrm{Pd}$ & $\mathrm{Ht}$ & $\mathrm{Gi}$ & St & Pmic & At & As & Gc & $\mathrm{Lp}$ \\
\hline Isochrysis galbana & $\mathrm{Y}$ & $\mathrm{Y}$ & $\mathrm{Y}$ & $\mathrm{Y}$ & $\mathrm{Y}$ & $\mathrm{Y}$ & $\mathrm{Y}$ & $\mathrm{Y}$ & $\mathrm{Y}$ & $\mathrm{Y}$ & $\mathrm{Y}$ \\
\hline Unidentified cryptophyte & $\mathrm{Y}$ & $\mathrm{Y}$ & $\mathrm{Y}$ & $\mathrm{Y}$ & $\mathrm{Y}$ & $\mathrm{Y}$ & $\mathrm{Y}$ & $\mathrm{Y}$ & $\mathrm{Y}$ & $\mathrm{Y}$ & $\mathrm{Y}$ \\
\hline Amphidinium carterae & $\mathrm{Y}$ & $\mathrm{Y}$ & $\mathrm{Y}$ & $\mathrm{Y}$ & $\mathrm{Y}$ & $\mathrm{Y}$ & $\mathrm{Y}$ & $\mathrm{Y}$ & $\mathrm{Y}$ & $\mathrm{Y}$ & $\mathrm{Y}$ \\
\hline Rhodomonas salina & $\mathrm{Y}$ & $\mathrm{Y}$ & $\mathrm{Y}$ & $\mathrm{Y}$ & $\mathrm{Y}$ & $\mathrm{Y}$ & $\mathrm{Y}$ & $\mathrm{Y}$ & $\mathrm{Y}$ & $\mathrm{Y}$ & $\mathrm{Y}$ \\
\hline Heterosigma akashiwo & $\mathrm{Y}$ & $\mathrm{Y}$ & $\mathrm{Y}$ & $\mathrm{Y}$ & $\mathrm{Y}$ & $\mathrm{Y}$ & $\mathrm{Y}$ & $\mathrm{Y}$ & $\mathrm{Y}$ & $\mathrm{Y}$ & $\mathrm{Y}$ \\
\hline Prorocentrum minimum & & $\mathrm{Y}$ & $\mathrm{Y}$ & $\mathrm{Y}$ & $\mathrm{N}$ & $\mathrm{Y}$ & $\mathrm{Y}$ & $\mathrm{Y}$ & $\mathrm{Y}$ & $\mathrm{Y}$ & $\mathrm{Y}$ \\
\hline Prorocentrum triestinum & $\mathrm{N}$ & & $\mathrm{N}$ & $\mathrm{N}$ & $\mathrm{N}$ & $\mathrm{N}$ & $\mathrm{Y}$ & $\mathrm{N}$ & $\mathrm{Y}$ & $\mathrm{N}$ & $\mathrm{Y}$ \\
\hline Prorocentrum donghaiense & $\mathrm{N}$ & $\mathrm{N}$ & & $\mathrm{N}$ & $\mathrm{N}$ & $\mathrm{N}$ & $\mathrm{Y}$ & $\mathrm{N}$ & $\mathrm{Y}$ & $\mathrm{N}$ & $\mathrm{Y}$ \\
\hline Heterocapsa triquetra & $\mathrm{N}$ & $\mathrm{N}$ & $\mathrm{N}$ & & $\mathrm{N}$ & $\mathrm{N}$ & $\mathrm{Y}$ & $\mathrm{N}$ & $\mathrm{Y}$ & $\mathrm{N}$ & $\mathrm{Y}$ \\
\hline Scrippsiella trochoidea & $\mathrm{N}$ & $\mathrm{N}$ & $\mathrm{N}$ & $\mathrm{N}$ & $\mathrm{N}$ & & $\mathrm{N}$ & $\mathrm{N}$ & $\mathrm{Y}$ & $\mathrm{N}$ & $\mathrm{Y}$ \\
\hline Cochlodinium polykrikoides & $\mathrm{N}$ & $\mathrm{N}$ & $\mathrm{N}$ & $\mathrm{N}$ & $\mathrm{N}$ & $\mathrm{N}$ & $\mathrm{N}$ & $\mathrm{N}$ & $\mathrm{N}$ & $\mathrm{N}$ & $\mathrm{N}$ \\
\hline Prorocentrum micans & $\mathrm{N}$ & $\mathrm{N}$ & $\mathrm{N}$ & $\mathrm{N}$ & $\mathrm{N}$ & $\mathrm{N}$ & & $\mathrm{N}$ & $\mathrm{N}$ & $\mathrm{N}$ & $\mathrm{N}$ \\
\hline Alexandrium tamarense & $\mathrm{N}$ & $\mathrm{N}$ & $\mathrm{N}$ & $\mathrm{N}$ & $\mathrm{N}$ & $\mathrm{N}$ & $\mathrm{N}$ & & $\mathrm{Y}$ & $\mathrm{N}$ & $\mathrm{Y}$ \\
\hline Akashiwo sanguinea & $\mathrm{N}$ & $\mathrm{N}$ & $\mathrm{N}$ & $\mathrm{N}$ & $\mathrm{N}$ & $\mathrm{N}$ & $\mathrm{N}$ & $\mathrm{N}$ & & $\mathrm{N}$ & $\mathrm{N}$ \\
\hline Gymnodinium catenatum & $\mathrm{N}$ & $\mathrm{N}$ & $\mathrm{N}$ & $\mathrm{N}$ & $\mathrm{N}$ & $\mathrm{N}$ & $\mathrm{N}$ & $\mathrm{N}$ & $\mathrm{N}$ & & $\mathrm{N}$ \\
\hline Lingulodinium polyedrum & $\mathrm{N}$ & $\mathrm{N}$ & $\mathrm{N}$ & $\mathrm{N}$ & $\mathrm{N}$ & $\mathrm{N}$ & $\mathrm{N}$ & $\mathrm{N}$ & $\mathrm{N}$ & $\mathrm{N}$ & \\
\hline
\end{tabular}



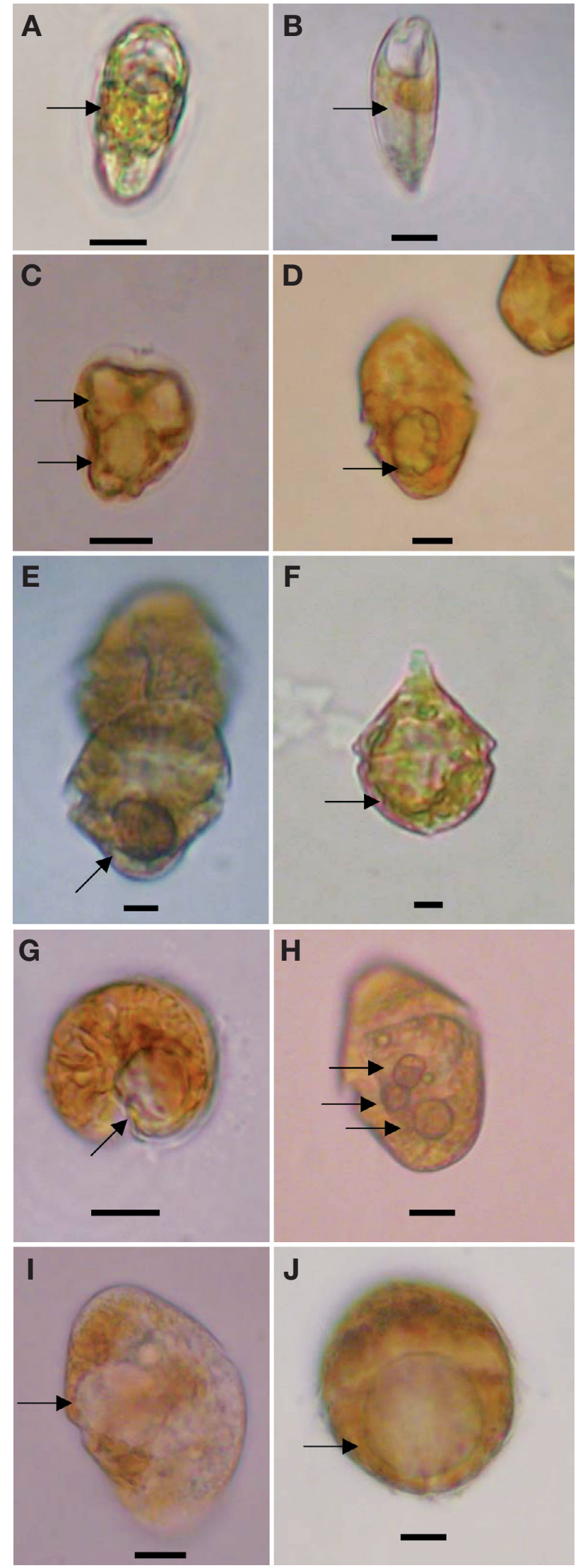

of approximately 110 to $480 \mathrm{ng} \mathrm{C} \mathrm{ml}^{-1}$ (i.e. 6410 to 28240 cells ml$^{-1}$ ) (Figs. 5 to 7 ). When the data were fitted to Eq. (2), the maximum specific growth rate of $P$. donghaiense, $H$. triquetra, and $P$. micans on a cryptophyte (mixotrophic growth) was $0.510,0.283$, and $0.197 \mathrm{~d}^{-1}$, respectively, under a 14:10 h light:dark cycle of $20 \mu \mathrm{E} \mathrm{m}{ }^{-2}$ $\mathrm{s}^{-1}$, while its growth rate under the same light conditions without any added prey (phototrophic growth) was only $0.375,0.184$, and $0.106 \mathrm{~d}^{-1}$, respectively.

With increasing mean prey concentration the specific growth rates of Lingulodinium polyedrum on Prorocentrum minimum increased, with saturation at a mean prey concentration of approximately $210 \mathrm{ng} \mathrm{C}$ $\mathrm{ml}^{-1}$ (i.e. 1620 cells $\mathrm{ml}^{-1}$ ) (Fig. 8). When the data were fitted to Eq. (2), the maximum specific growth rate of $L$. polyedrum on $P$. minimum (mixotrophic growth) was $0.254 \mathrm{~d}^{-1}$, under a 14:10 h light:dark cycle of $50 \mu \mathrm{E} \mathrm{m} \mathrm{m}^{-2}$ $\mathrm{s}^{-1}$, while its growth rate under the same light conditions without added prey (phototrophic growth) was only $0.157 \mathrm{~d}^{-1}$.

With increasing mean prey concentration the specific growth rates of Lingulodinium polyedrum on Scrippsiella trochoidea increased, with saturation at a mean prey concentration of approximately $170 \mathrm{ng} \mathrm{C}$ $\mathrm{ml}^{-1}$ (i.e. 250 cells $\mathrm{ml}^{-1}$ ) (Fig. 9). When the data were fitted to Eq. (2), the maximum specific growth rate of $L$. polyedrum on $S$. trochoidea (mixotrophic growth) was $0.303 \mathrm{~d}^{-1}$, under a 14:10 h light:dark cycle of $50 \mu \mathrm{E} \mathrm{m} \mathrm{m}^{-2}$ $\mathrm{s}^{-1}$, while its growth rate under the same light conditions without added prey (phototrophic growth) was only $0.182 \mathrm{~d}^{-1}$.

The ingestion rates of Prorocentrum donghaiense, Heterocapsa triquetra, and P. micans on a cryptophyte increased continuously with increasing mean prey concentration offered in the present study (Figs. 10 to 12). When the data were fitted to Eq. (3), the maximum ingestion rate of $P$. donghaiense, $H$. triquetra, and $P$. micans on a cryptophyte were $0.026,0.038$, and $0.041 \mathrm{ng}$ C grazer ${ }^{-1} \mathrm{~d}^{-1}\left(1.5,2.2\right.$, and 2.4 cells grazer ${ }^{-1} \mathrm{~d}^{-1}$, respectively). The maximum clearance rates of $P$. donghaiense, $H$. triquetra, and $P$. micans on a cryptophyte were 0.041 , 0.051 , and $0.054 \mu$ grazer $^{-1} \mathrm{~h}^{-1}$, respectively.

Fig. 1. Feeding by algal predators on algal prey. (A) Prorocentrum donghaiense with an ingested Amphidinium carterae cell. (B) P. triestinum with an ingested cryptophyte cell. (C) P. minimum with ingested Heterosigma akashiwo cells. (D) Heterocapsa triquetra with an ingested $H$. akashiwo cell. (E) Gymnodinium impudicum with an ingested $H$. akashiwo cell. (F) Scrippsiella trochoidea with an ingested P. minimum cell. (G) Alexandrium tamarense with an ingested $H$. akashiwo cell. (H) G. catenatum with ingested $H$. akashiwo cells. (I) Akashiwo sanguinea with an ingested A. tamarense cell. (J) Lingulodinium polyedrum with an ingested A. tamarense cell. Arrows indicate prey cells. Scale bars $=5 \mu \mathrm{m}$ (A to $\mathrm{F}$ ) and $10 \mu \mathrm{m}$ ( $\mathrm{G}$ to $\mathrm{J}$ ) 
Fig. 2. Feeding process by Prorocentrum micans on a cryptophyte cell. These pictures in sequence were taken using a digital camera on a compound microscope. (A) $P$. micans has captured a cryptophyte cell. (B-C) P. micans has engulfed approximately $1 / 2$ of the body of a cryptophyte cell. (D) P. micans has engulfed approximately $3 / 4$ of the body of a cryptophyte cell. (E-F) $P$. micans has almost engulfed a cryptophyte cell. Arrows indicate the prey cell. The predator and prey cells in (A) to (F) were the same. (A), (B), (D) and (E) are phase photomicrographs and $(\mathrm{C})$ and $(\mathrm{F})$ are photomicrographs taken using epifluorescence. Scale bars $=10 \mu \mathrm{m}$
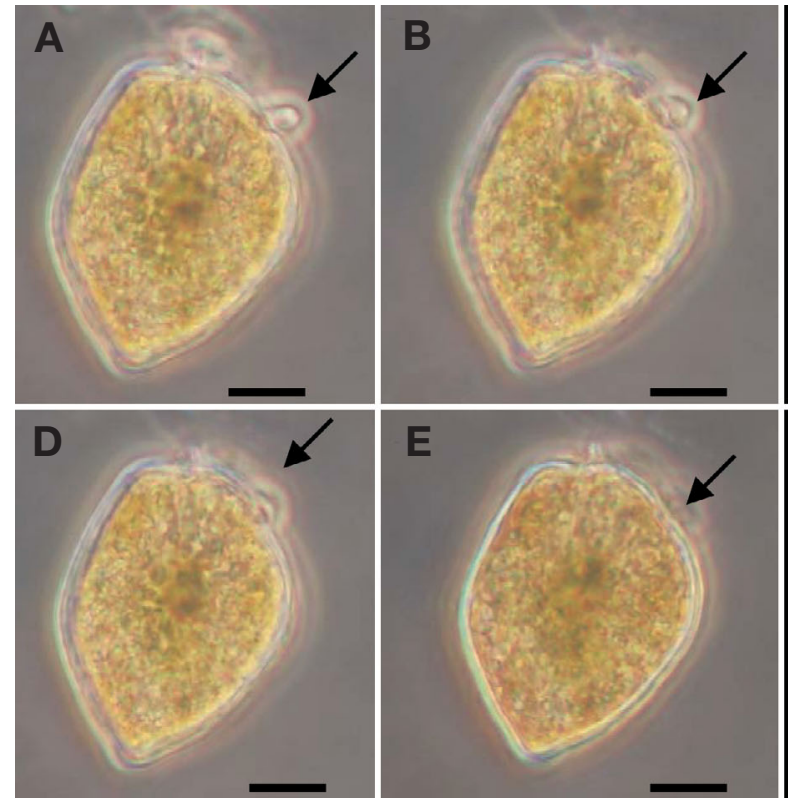
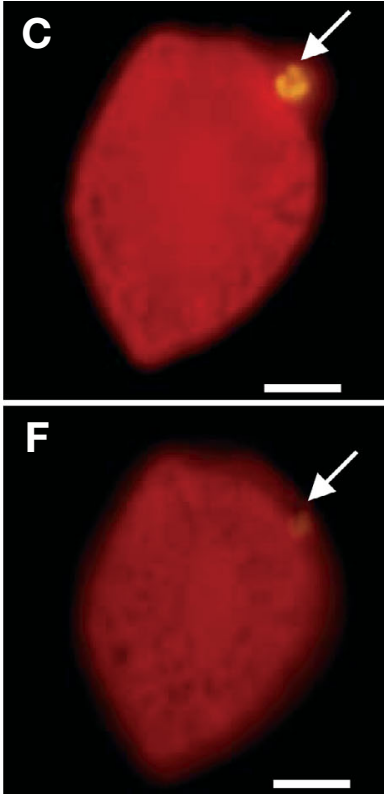

With increasing mean prey concentration the ingestion rates of Lingulodinium polyedrum on Prorocentrum minimum increased, with saturation at a mean prey concentration of approximately $1180 \mathrm{ng} \mathrm{C} \mathrm{ml}^{-1}$ (i.e. 9080 cells $\mathrm{ml}^{-1}$ ) (Fig. 13). When the data were fitted to Eq. (3), the maximum ingestion rate of $L$. polyedrum on $P$. minimum was $0.20 \mathrm{ng} \mathrm{C}$ grazer $^{-1} \mathrm{~d}^{-1}$ (1.5 cells grazer $\left.{ }^{-1} \mathrm{~d}^{-1}\right)$. The maximum clearance rate of L. polyedrum on $P$. minimum was $0.13 \mu$ grazer $^{-1} \mathrm{~h}^{-1}$.

The ingestion rates of Lingulodinium polyedrum feeding on a unialgal diet of Scrippsiella trochoidea increased continuously with increasing mean prey concentration offered in the present study (Fig. 14). When the data were fitted to Eq. (3), the maximum ingestion rate of $L$. polyedrum on $S$. trochoidea was 0.36 ng C grazer ${ }^{-1} \mathrm{~d}^{-1}\left(0.5\right.$ cells grazer $\left.{ }^{-1} \mathrm{~d}^{-1}\right)$. The maximum clearance rate of $L$. polyedrum on $S$. trochoidea was $0.14 \mu$ grazer $^{-1} \mathrm{~h}^{-1}$.

\section{Potential grazing impact}

Grazing coefficients attributable to Prorocentrum donghaiense on co-occurring cryptophytes in the coastal waters off Kohung, Kwangyang, Tongyoung, and Masan, Korea, were up to $2.67 \mathrm{~h}^{-1}$, while those attributable to Heterocapsa triquetra on co-occurring cryptophytes in the waters of Masan Bay, Korea, were up to $0.091 \mathrm{~h}^{-1}$ (Fig. 15A,B). In addition, grazing coefficients attributable to $P$. micans on co-occurring cryptophytes in the coastal waters off Kohung, Tongyoung, and Masan, Korea, were up to $0.043 \mathrm{~h}^{-1}$ (Fig. 15C).

Grazing coefficients attributable to Lingulodinium polyedrum on co-occurring small Prorocentrum spp. ( $P$. minimum $+P$. triestinum) in the coastal waters off Kohung and Saemankeum, Korea, and in the Krka Estuary, Croatia, were up to $0.026 \mathrm{~h}^{-1}$ (Fig. 15D), while those on co-occurring Scrippsiella trochoidea in the waters in the Los Angeles-Long Beach harbor, USA, and Kohung and Saemankeum, Korea, were up to $0.011 \mathrm{~h}^{-1}$ (Fig. 15E).

\section{DISCUSSION}

\section{Mixotrophy in red-tide dinoflagellates}

We report here for the first time that 5 red-tide dinoflagellates (Gymnodinium catenatum, G. impudicum, Lingulodinium polyedrum, Prorocentrum donghaiense, and P. triestinum) which had been previously thought to be exclusively autotrophic dinoflagellates, are mixotrophic species. Before the present study, approximately 40 marine dinoflagellates have been reported to be mixotrophic (reviewed by Stoecker 1999, Jeong et al. 2004, 2005). Most dinoflagellates may be mixotrophic species, but the trophic modes of many dinoflagellates have not been tested yet to ascertain whether they are exclusively autotrophic or mixotrophic. To understand the ecology and physiology of these dinoflagellates better, their trophic modes should be revealed.

\section{Algal predators and prey species}

All algal predators tested in the present study were able to feed on phytoplankton belonging to diverse classes such as Prymnesiophyceae, Cryptophyceae, Raphidophyceae, and Dinophyceae. However, in gen- 

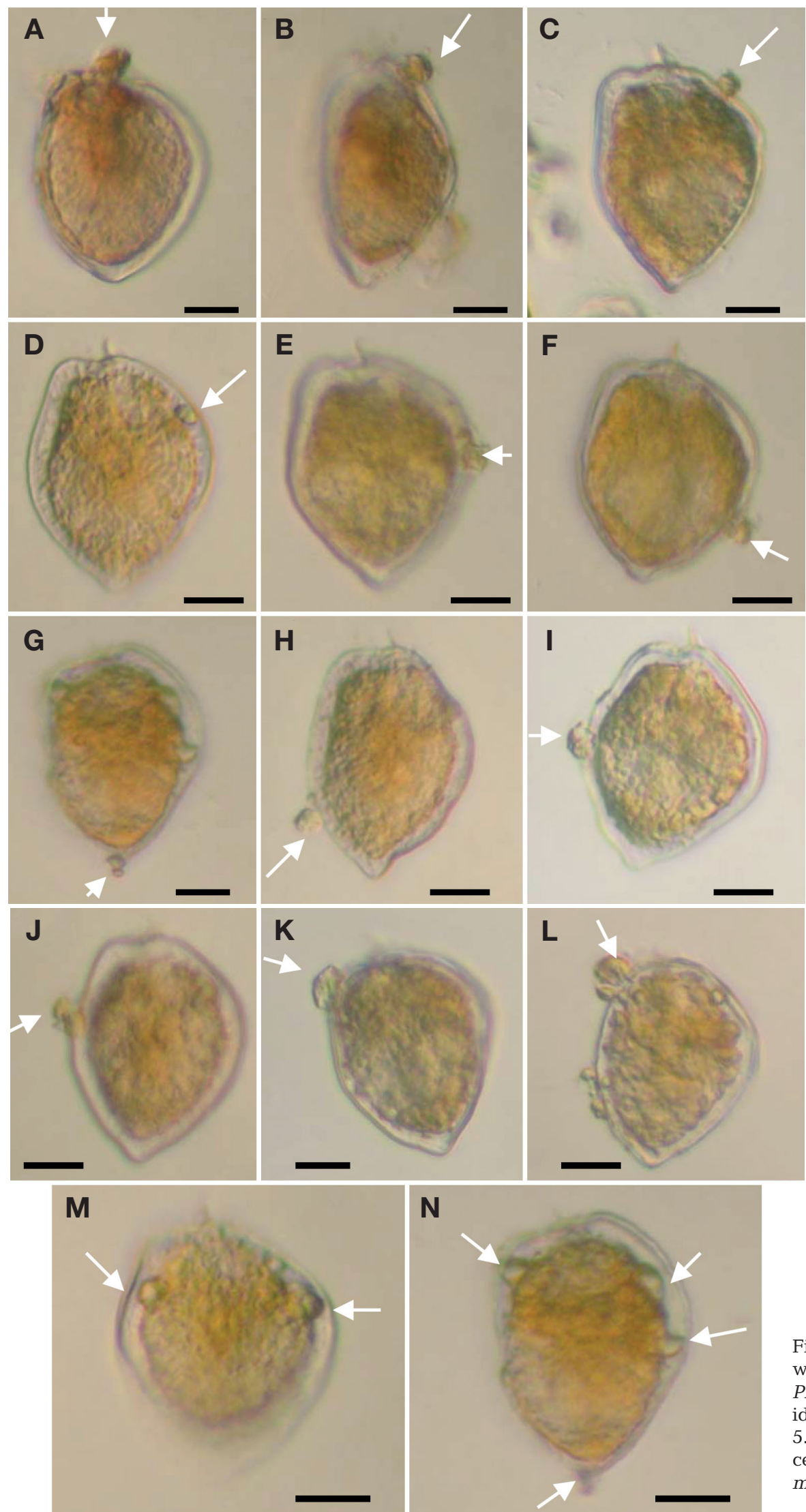

Fig. 3. (A-L) Diverse sites through which prey cells were engulfed when Prorocentrum micans fed on an unidentified cryptophyte species $(\mathrm{ESD}=$ $5.6 \mu \mathrm{m})$. Two (M) and $4(\mathrm{~N})$ cryptophyte cells simultaneously engulfed by a $P$. micans cell. Arrows indicate prey cells. Scale bars $=10 \mu \mathrm{m}$ 


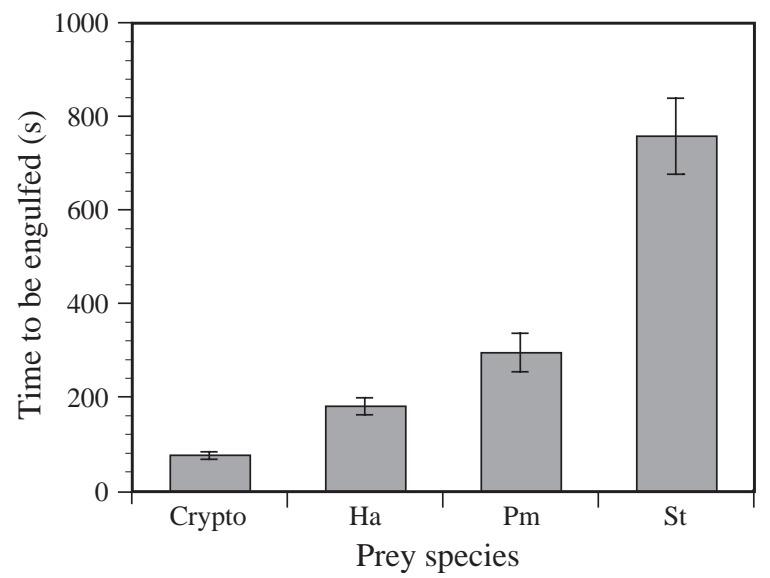

Fig. 4. Mean time $( \pm \mathrm{SE})$ for a cryptophyte $($ Crypto; $\mathrm{ESD}=$ $5.6 \mu \mathrm{m})$, Heterosigma akashiwo (Ha), Prorocentrum minimum (Pm), and Scrippsiella trochoidea cell (St) to be completely engulfed through the sulcus of Lingulodinium polyedrum after the prey cell was contacted by the predator. $\mathrm{N}=5$ to 7 for each prey species

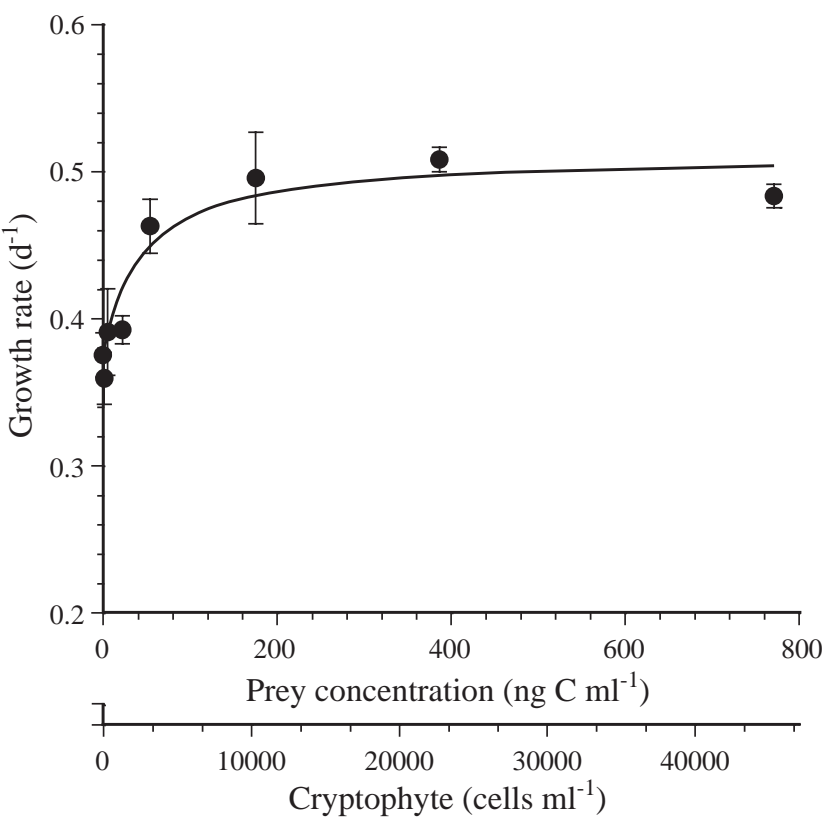

Fig. 5. Specific growth rates $\left(\mathrm{d}^{-1}\right)$ of Prorocentrum donghaiense on an unidentified cryptophyte $(\mathrm{ESD}=5.6 \mu \mathrm{m})$ as a function of mean prey concentration ( $\mathrm{ng} \mathrm{C} \mathrm{ml}^{-1}$ and cells $\mathrm{ml}^{-1}$ ). Symbols represent treatment means $\pm 1 \mathrm{SE}$. The curves were fitted by a Michaelis-Menten equation (Eq. 2) using all treatments in the experiment. Growth rate $\left(G R, d^{-1}\right)=$ $0.510\{(x+32) /[12+(x+32)]\}, r^{2}=0.47$

eral, whether these algal predators are able to ingest a phytoplankton species or not appears to be mainly affected by the sizes of the prey and predator species; all algal predators tested in the present study ingested the small phytoplankton species which had ESD < $12 \mu \mathrm{m}$. All the algal predators which had ESDs $\geq$ $12.6 \mu \mathrm{m}$ were able to feed on Prorocentrum minimum.

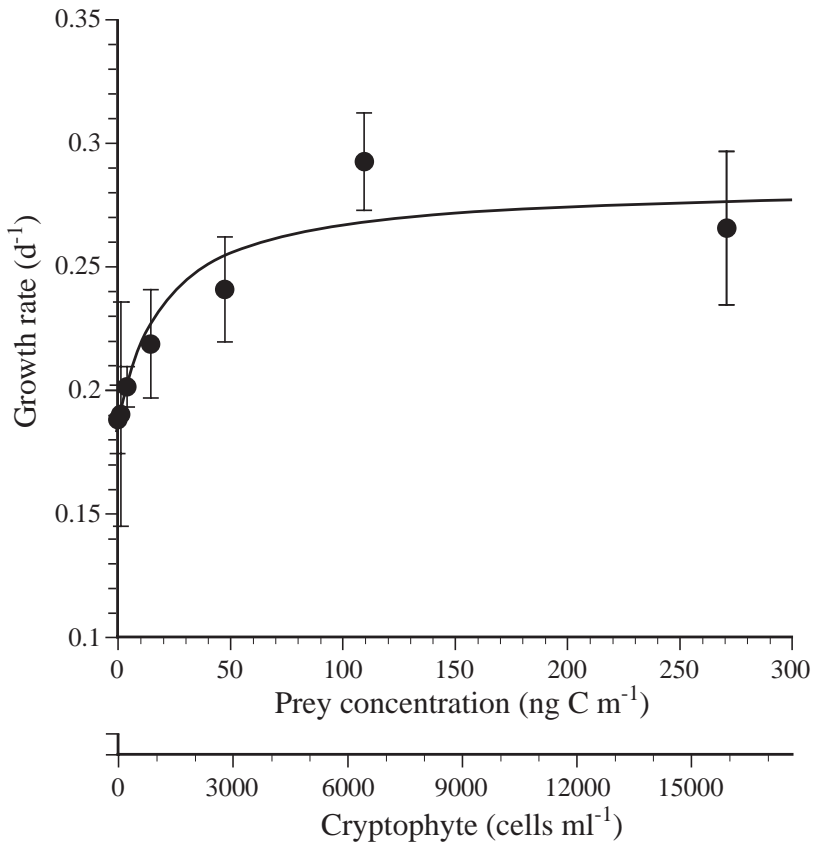

Fig. 6. Specific growth rates $\left(\mathrm{d}^{-1}\right)$ of Heterocapsa triquetra on an unidentified cryptophyte $(\mathrm{ESD}=5.6 \mu \mathrm{m})$ as a function of mean prey concentration (ng C ml-1 and cells $\mathrm{ml}^{-1}$ ). Symbols represent treatment means $\pm 1 \mathrm{SE}$. The curve was fitted by a Michaelis-Menten equation (Eq. 2) using all treatments in the experiment. Growth rate $\left(\mathrm{GR}_{,} \mathrm{d}^{-1}\right)=0.283\{(x+12.6) /$ $[6.8+(x+12.6)]\}, \mathrm{r}^{2}=0.42$

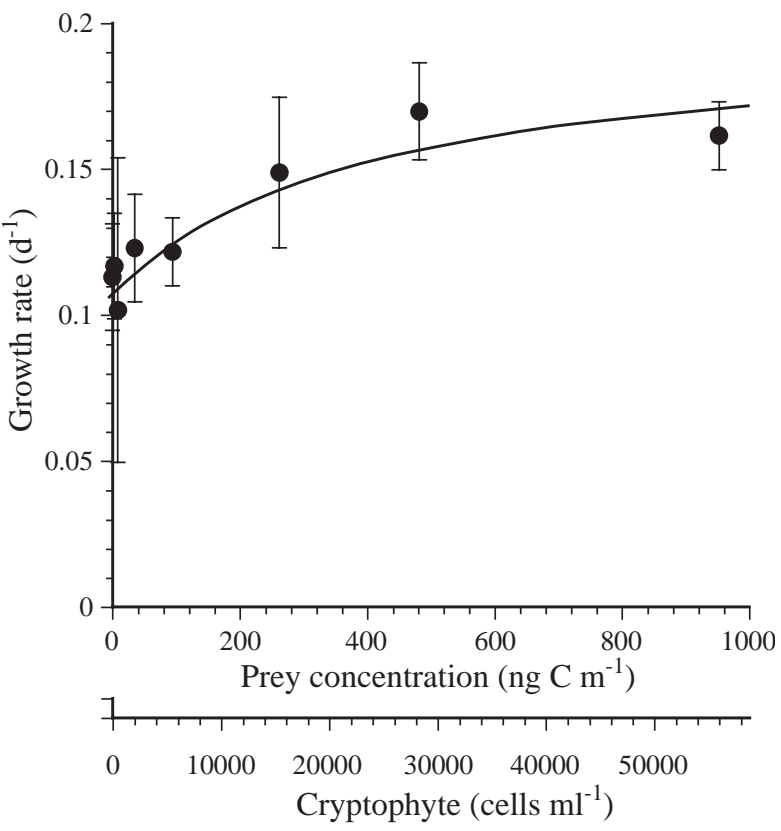

Fig. 7. Specific growth rates $\left(\mathrm{d}^{-1}\right)$ of Prorocentrum micans on an unidentified cryptophyte $(E S D=5.6 \mu \mathrm{m})$ as a function of mean prey concentration (ng C ml$l^{-1}$ and cells $\mathrm{ml}^{-1}$ ). Symbols represent treatment means $\pm 1 \mathrm{SE}$. The curve was fitted by a Michaelis-Menten equation (Eq. 2) using all treatments in the experiment. Growth rate $\left(G R, d^{-1}\right)=0.197\{(x+211)$ / $[181+(x+211)]\}, r^{2}=0.26$ 


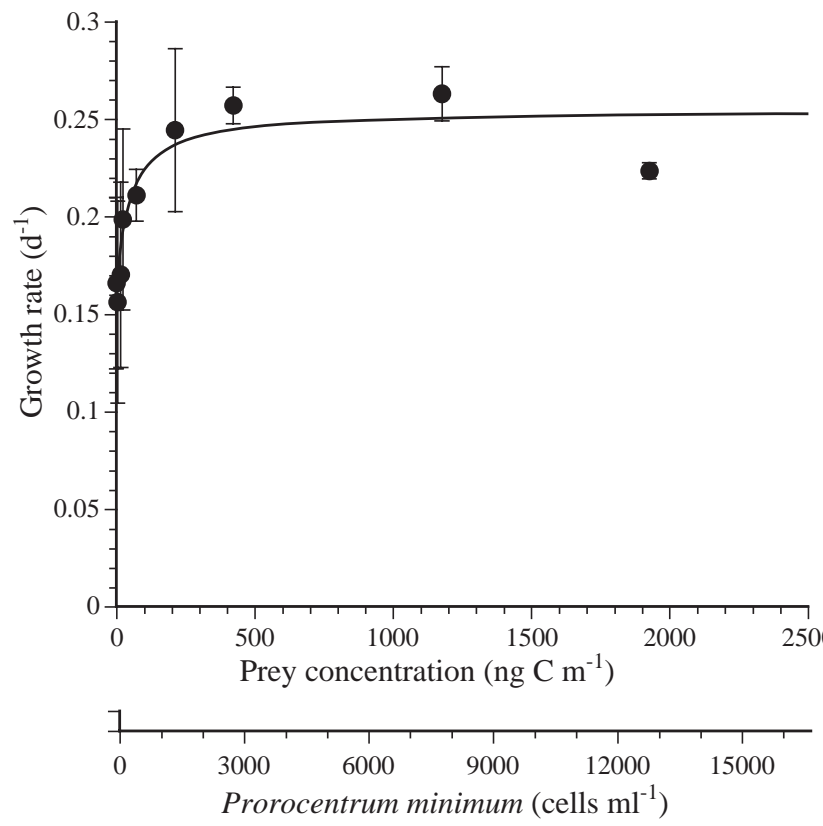

Fig. 8. Specific growth rates $\left(\mathrm{d}^{-1}\right)$ of Lingulodinium polyedrum on Prorocentrum minimum as a function of mean prey concentration (ng C ml-1 and cells $\mathrm{ml}^{-1}$ ). Symbols represent treatment means $\pm 1 \mathrm{SE}$. The curve was fitted by a MichaelisMenten equation (Eq. 2 using all treatments in the experiment. Growth rate $\left(\mathrm{GR}, \mathrm{d}^{-1}\right)=0.254\{(x+30) /[18+(x+30)]\}$,

$$
\mathrm{r}^{2}=0.32
$$

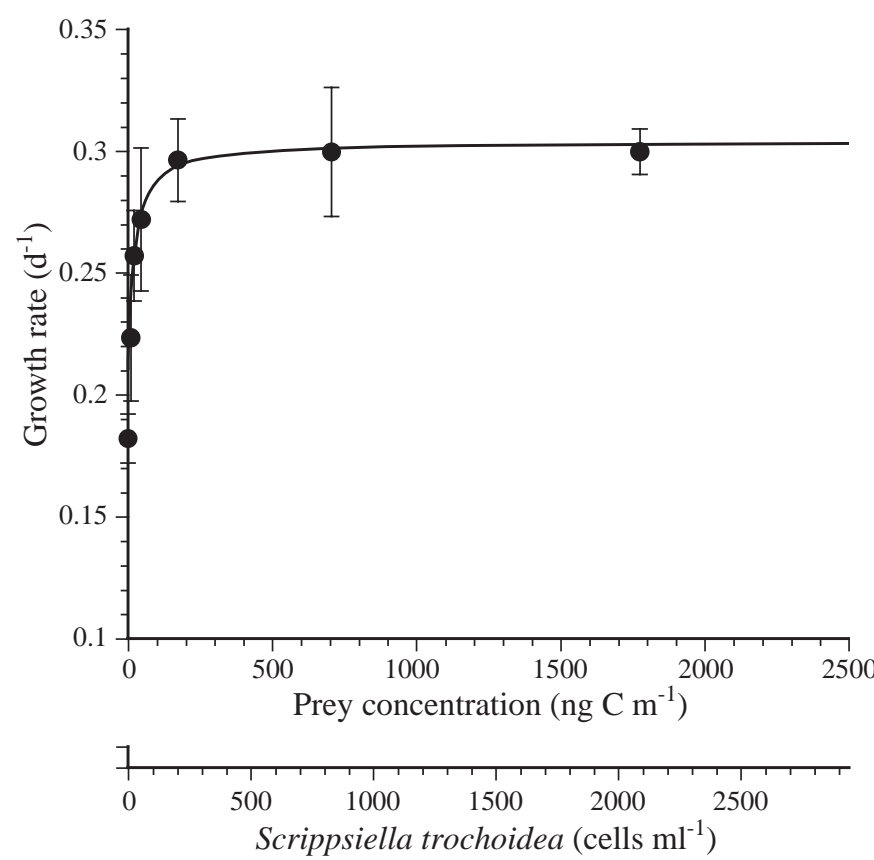

Fig. 9. Specific growth rates $\left(\mathrm{d}^{-1}\right)$ of Lingulodinium polyedrum on Scrippsiella trochoidea as a function of mean prey concentration (ng C ml-1 and cells $\mathrm{ml}^{-1}$ ). Symbols represent treatment means $\pm 1 \mathrm{SE}$. The curve was fitted by a Michaelis-Menten equation (Eq. 2) using all treatments in the experiment. Growth rate $\left(\mathrm{GR} \mathrm{d}^{-1}\right)=0.303\{(x+10) /$

$$
[6+(x+10)]\}, r^{2}=0.67
$$

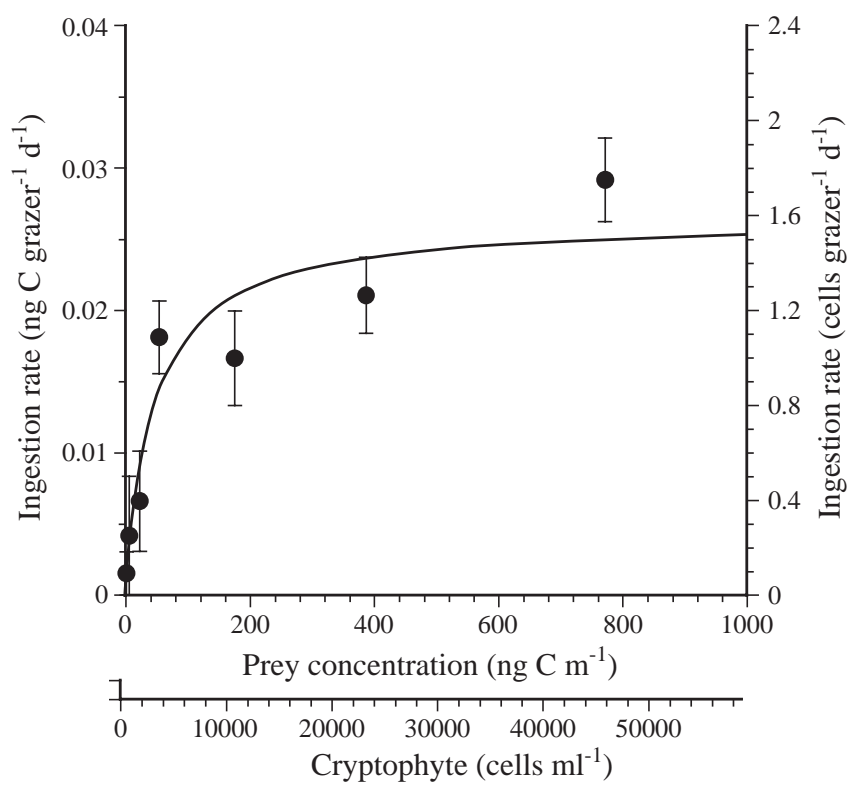

Fig. 10. Ingestion rate (ng C grazer ${ }^{-1} \mathrm{~d}^{-1}$ and cells grazer ${ }^{-1} \mathrm{~d}^{-1}$ ) of Prorocentrum donghaiense on an unidentified cryptophyte $(\mathrm{ESD}=5-6 \mu \mathrm{m})$ as a function of mean prey concentration (ng $\mathrm{C} \mathrm{ml}^{-1}$ and cells $\mathrm{ml}^{-1}$ ). Symbols represent treatment means \pm 1 SE. The curve was fitted by a Michaelis-Menten equation (Eq. 3) using all treatments in the experiment. Ingestion rate $\left(\mathrm{IR}, \mathrm{ng} \mathrm{C}\right.$ grazer $\left.^{-1} \mathrm{~d}^{-1}\right)=0.026[x /(44.7+x)], \mathrm{r}^{2}=0.731$

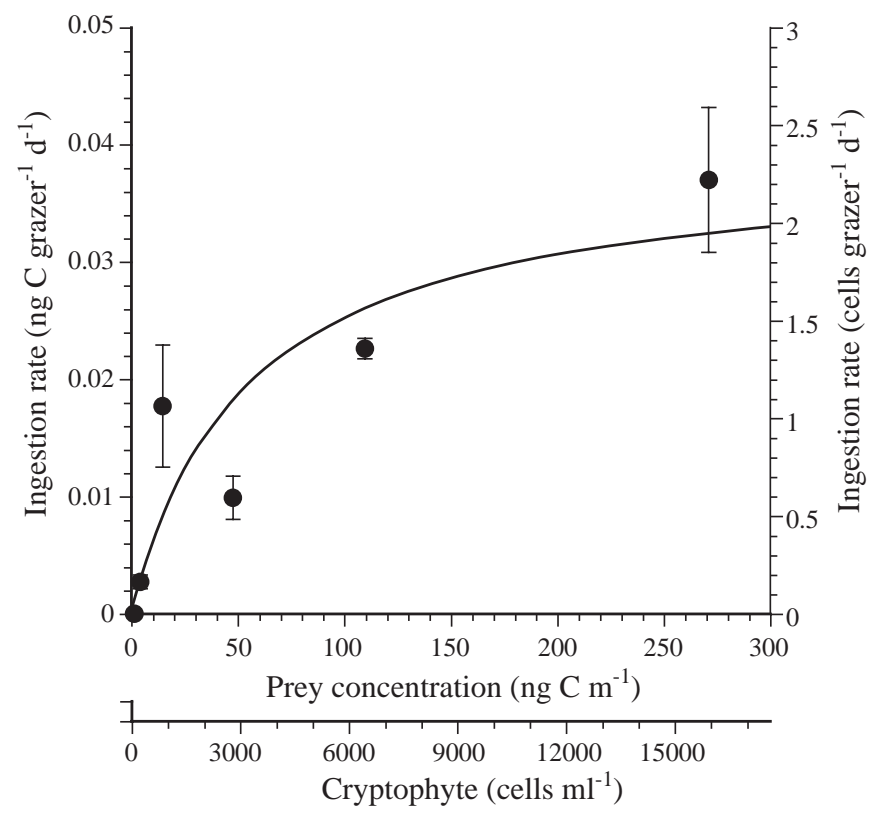

Fig. 11. Ingestion rate (ng C grazer ${ }^{-1} \mathrm{~d}^{-1}$ and cells grazer ${ }^{-1} \mathrm{~d}^{-1}$ ) of Heterocapsa triquetra on an unidentified cryptophyte (ESD $=5.6 \mu \mathrm{m})$ as a function of mean prey concentration $\left(\mathrm{ng} \mathrm{C} \mathrm{ml}^{-1}\right.$ and cells $\mathrm{ml}^{-1}$ ). Symbols represent treatment means $\pm 1 \mathrm{SE}$. The curve was fitted by a Michaelis-Menten equation (Eq. 3) using all treatments in the experiment. Ingestion rate $\left(\mathrm{IR}\right.$, ng C grazer $\left.{ }^{-1} \mathrm{~d}^{-1}\right)=0.038[x /(48.8+x)], \mathrm{r}^{2}=0.689$ 


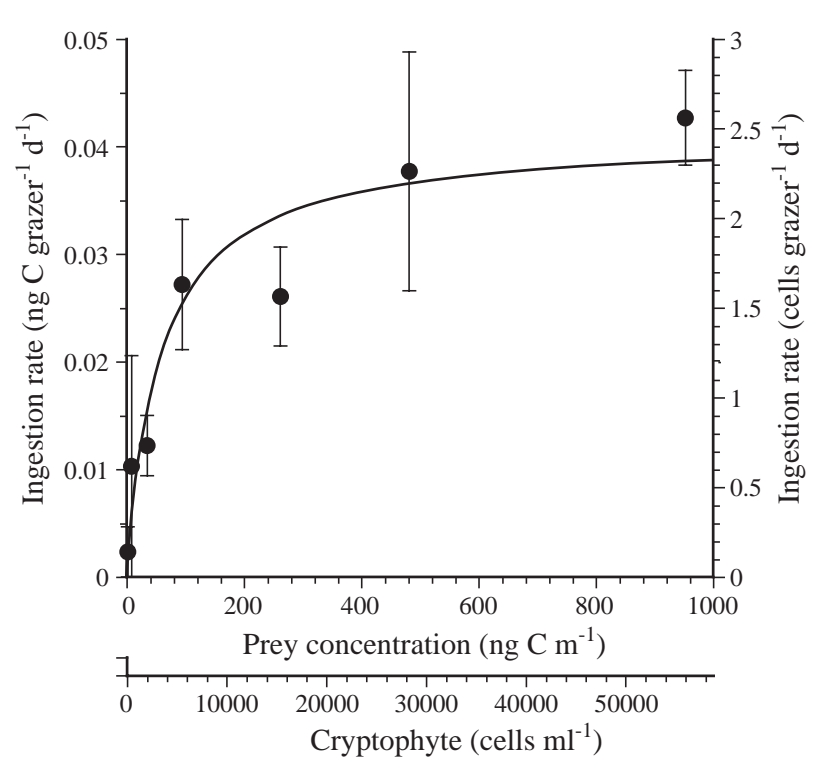

Fig. 12. Ingestion rate (ng $\mathrm{C}$ grazer ${ }^{-1} \mathrm{~d}^{-1}$ and cells grazer ${ }^{-1} \mathrm{~d}^{-1}$ ) of Prorocentrum micans on an unidentified cryptophyte as a function of mean prey concentration (ng C ml-1 and cells $\mathrm{ml}^{-1}$ ). Symbols represent treatment means $\pm 1 \mathrm{SE}$. The curve was fitted by a Michaelis-Menten equation (Eq. 3) using all treatments in the experiment. Ingestion rate (IR, ng $\mathrm{C}$ grazer $\left.^{-1} \mathrm{~d}^{-1}\right)=0.041[x /(59+x)], \mathrm{r}^{2}=0.62$

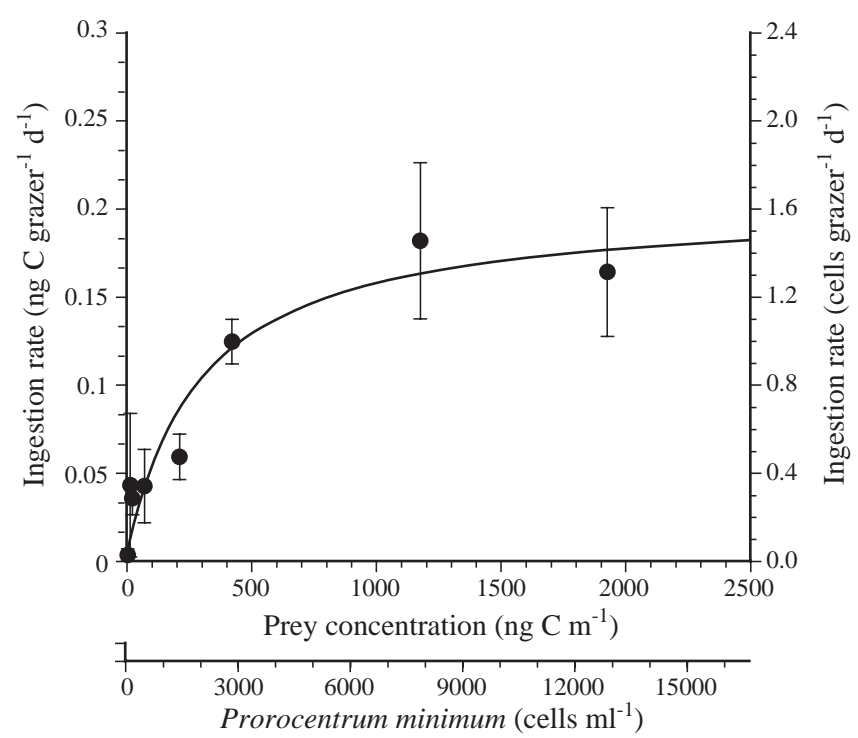

Fig. 13. Ingestion rate (ng $C$ grazer ${ }^{-1} \mathrm{~d}^{-1}$ and cells grazer ${ }^{-1} \mathrm{~d}^{-1}$ ) of Lingulodinium polyedrum on Prorocentrum minimum as a function of mean prey concentration (ng C ml-1 and cells $\mathrm{ml}^{-1}$ ). Symbols represent treatment means $1 \mathrm{SE}$. The curve was fitted by a Michaelis-Menten equation (Eq. 3) using all treatments in the experiment. Ingestion rate (IR, ng C grazer ${ }^{-1}$

$$
\left.\mathrm{d}^{-1}\right)=0.20[\mathrm{x} /(292+\mathrm{x})], \mathrm{r}^{2}=0.66
$$

The large predators P. micans, Akashiwo sanguinea, and Lingulodinium polyedrum were able to ingest Heterocapsa triquetra which had an ESD of $15 \mu \mathrm{m}$. In addition, A. sanguinea and $L$. polyedrum were able to

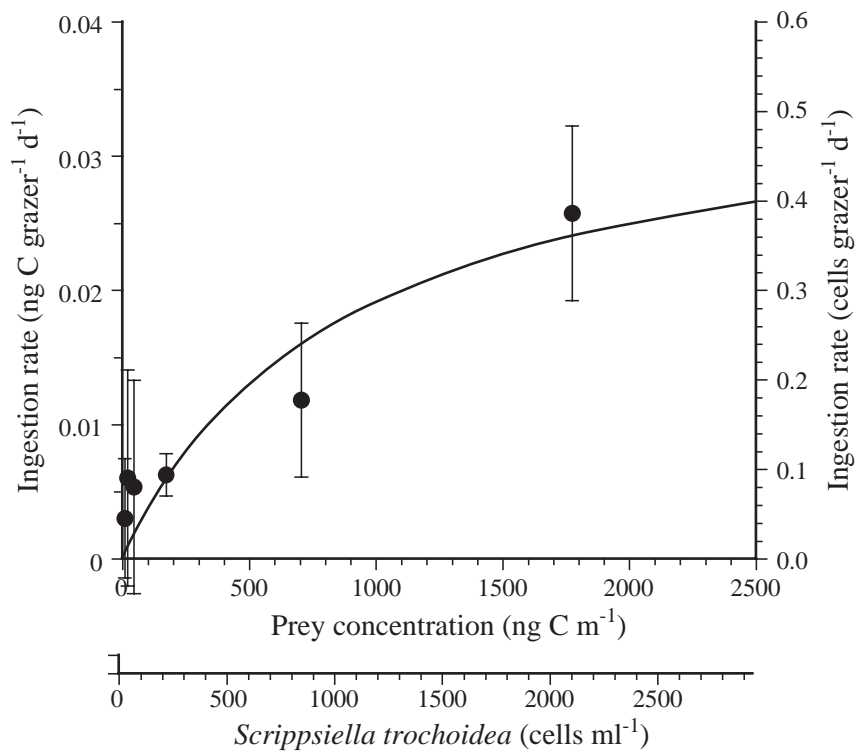

Fig. 14. Ingestion rate (ng C grazer ${ }^{-1} \mathrm{~d}^{-1}$ and cells grazer ${ }^{-1} \mathrm{~d}^{-1}$ ) of Lingulodinium polyedrum on Scrippsiella trochoidea as a function of mean prey concentration (ng C ml-1 and cells $\mathrm{ml}^{-1}$ ). Symbols represent treatment means $\pm 1 \mathrm{SE}$. The curve was fitted by a Michaelis-Menten equation (Eq. 3) using all treatments in the experiment. Ingestion rate (IR, ng $\mathrm{C}$ grazer $\left.^{-1} \mathrm{~d}^{-1}\right)=0.36[\mathrm{x} /(895+\mathrm{x})], \mathrm{r}^{2}=0.66$

ingest Scrippsiella trochoidea and Alexandrium tamarense which had ESDs of 23 to $28 \mu \mathrm{m}$. The length of the sulcus of $L$. polyedrum $(\mathrm{ESD}=38 \mu \mathrm{m})$ is almost $3 / 4$ of the whole body length due to a big displacement in the girdle. This long sulcus may be responsible for engulfing large prey species such as $A$. tamarense $(\mathrm{ESD}=$ $28 \mu \mathrm{m})$. However, A. sanguinea and L. polyedrum did not feed on Cochlodinium polykrikoides $(26 \mu \mathrm{m})$ and $P$. micans $(22 \mu \mathrm{m})$ (Table 3$)$. The maximum swimming speed of $C$. polykrikoides $\left(1450 \mu \mathrm{m} \mathrm{s}^{-1}\right)$ is much higher than that of $A$. sanguinea $\left(280 \mu \mathrm{m} \mathrm{s}^{-1}\right)$ or L. polyedrum (380 $\mathrm{m} \mathrm{s} \mathrm{s}^{-1}$ ) (Jeong et al. 1999). The high swimming speed of $C$. polykrikoides may be partially responsible for its not being eaten by L. polyedrum.

\section{Feeding behaviors}

Before the present study, the feeding mechanisms of Prorocentrum spp. had not been known. Surprisingly, Prorocentrum spp. fed on prey by engulfing the prey cell through the sutures on the sides of several parts of their bodies. This predator is also able to engulf several prey cells at several different sites simultaneously or consequently. Scrippsiella trochoidea fed on phytoplankton cells by engulfing the prey through the apical horn as well as the sulcus, as observed for Gonyaulax polygramma (Jeong et al. 2005). However, Heterocapsa triquetra and Lingulodinium polyedrum fed on phyto- 

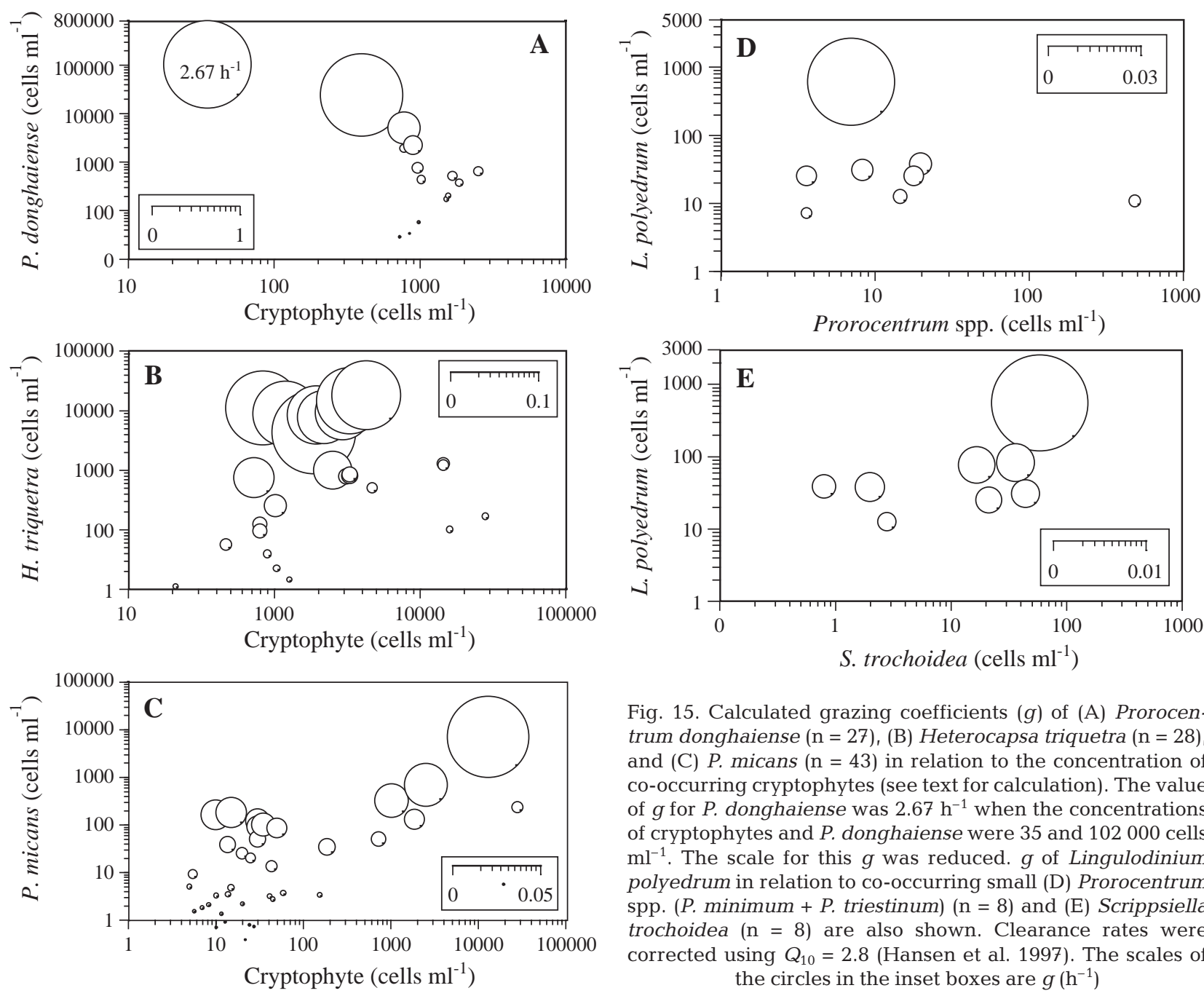

Fig. 15. Calculated grazing coefficients $(g)$ of (A) Prorocentrum donghaiense $(\mathrm{n}=27)$, (B) Heterocapsa triquetra $(\mathrm{n}=28)$, and $(C) P$. micans $(n=43)$ in relation to the concentration of co-occurring cryptophytes (see text for calculation). The value of $g$ for $P$. donghaiense was $2.67 \mathrm{~h}^{-1}$ when the concentrations of cryptophytes and $P$. donghaiense were 35 and 102000 cells $\mathrm{ml}^{-1}$. The scale for this $g$ was reduced. $g$ of Lingulodinium polyedrum in relation to co-occurring small (D) Prorocentrum spp. $(P$. minimum + P. triestinum $)(\mathrm{n}=8)$ and $($ E) Scrippsiella trochoidea $(\mathrm{n}=8)$ are also shown. Clearance rates were corrected using $Q_{10}=2.8$ (Hansen et al. 1997). The scales of the circles in the inset boxes are $g\left(\mathrm{~h}^{-1}\right)$

plankton cells by engulfing the prey through only the sulcus. The length of the apical horn of $H$. triquetra and L. polyedrum is much shorter than those of G. polygramma and $S$. trochoidea. Therefore, the mixotrophic dinoflagellates may need an elongated apical horn to capture prey cells through that part of their structure. In conclusion, Prorocentrum spp. are able to engulf prey cells from diverse directions, $S$. trochoidea and G. polygramma from 2 directions, and most other mixotrophic or heterotrophic dinoflagellates from 1 direction. However, ingesting prey cells from more directions may not cause higher ingestion rates because the maximum ingestion rate of $P$. donghaiense or $P$. micans on a cryptophyte was lower than that of G. polygramma.

\section{Growth and ingestion}

A unialgal diet of a cryptophyte can support a population growth of Prorocentrum donghaiense, Hetero-

capsa triquetra, and P. micans 36 to $86 \%$ higher than that without added prey under the conditions provided in the present study, while unialgal diets of $P$. minimum and Scrippsiella trochoidea can also support a population growth of Lingulodinium polyedrum 62 to $67 \%$ higher than that without added prey under the conditions provided in the present study. This evidence suggests that these algal predators may be able to increase or maintain their populations by feeding on the algal prey under conditions which are less favorable for phototrophic growth if prey is abundant. To predict the outbreak of red tides dominated by these algal predators, the co-occurring phytoplankton species should be taken into consideration.

The maximum ingestion rates of Lingulodinium polyedrum feeding on unialgal diets of Prorocentrum minimum and Scrippsiella trochoidea under the conditions provided in the present study $(0.20$ to $0.36 \mathrm{ng} \mathrm{C}$ grazer $^{-1} \mathrm{~d}^{-1}$ ) were comparable to or higher than those of Cochlodinium polykrikoides (0.16 ng $\mathrm{C} \mathrm{grazer}^{-1} \mathrm{~d}^{-1}$ ) 
and Gonyaulax polygramma (0.18) on a cryptophyte $(\mathrm{ESD}=5.6 \mu \mathrm{m})$ obtained under a $14: 10 \mathrm{~h}$ light:dark cycle of $50 \mu \mathrm{E} \mathrm{m} \mathrm{m}^{-2} \mathrm{~s}^{-1}$ (Jeong et al. 2004, 2005). However, the maximum clearance rates of $L$. polyedrum feeding on unialgal diets of $P$. minimum and $S$. trochoidea under the conditions provided in the present study $\left(0.13\right.$ to $0.14 \mu$ grazer $\left.^{-1} \mathrm{~h}^{-1}\right)$ were comparable to or lower than those of $C$. polykrikoides $(0.33 \mu \mathrm{l}$ grazer $^{-1} \mathrm{~h}^{-1}$ ) and G. polygramma (0.18) on a cryptophyte. The lower swimming speed of $L$. polyedrum and consequent lower encounter rate between the predator and prey cells compared with that of C. polykrikoides may cause the maximum clearance rate of L. polyedrum to be lower than that of C. polykrikoides. Data from these studies show that maximum ingestion rates of 5 red-tide dinoflagellates (Cochlodinium polykrikoides, Gonyaulax polygramma, Heterocapsa triquetra, Prorocentrum donghaiense, and P. micans) on a cryptophyte and L. polyedrum on unialgal diets of $P$. minimum and $S$. trochoidea are positively correlated with the ESDs of the dinoflagellates (Fig. 16). This relationship suggests that the sizes of the algal predators may be an important factor affecting their maximum ingestion rates on the algal prey. However, the maximum ingestion rate of $P$. micans (0.04 ng $\mathrm{C}_{\text {grazer }}{ }^{-1}$

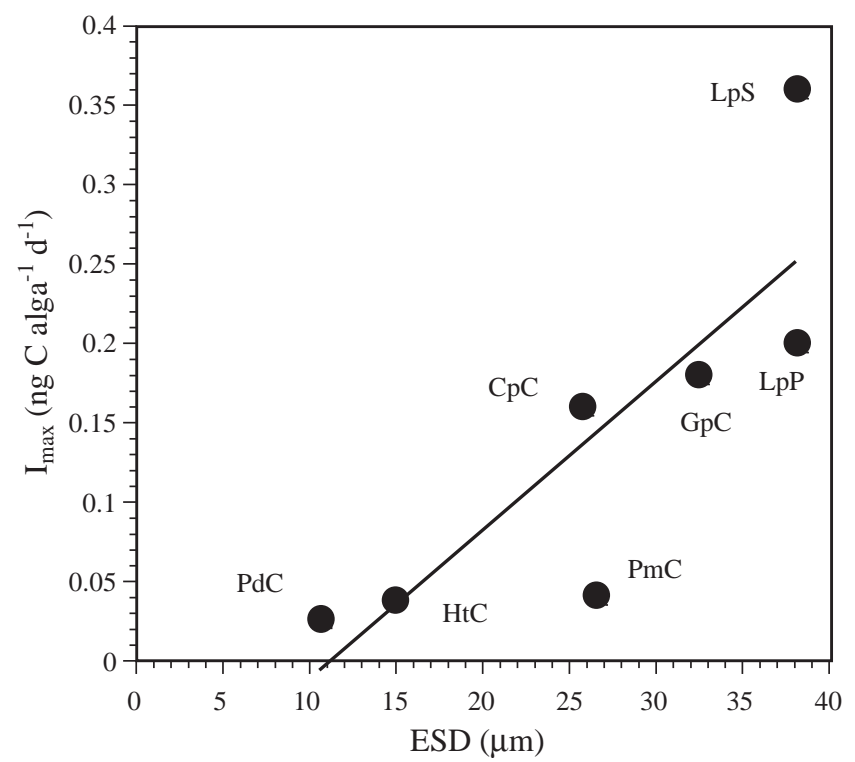

Fig. 16. Maximum ingestion rates $\left(I_{\max }\right)$ of 5 red-tide dinoflagellates on an unidentified cryptophyte species (ESD = $5.6 \mu \mathrm{m})$ and Lingulodinium polyedrum on Scrippsiella trochoidea and Prorocentrum minimum as a function of algal size $(E S D, \mu \mathrm{m})$. The equation of the linear regression was $I_{\max }$ $\left(\mathrm{ng} \mathrm{C}\right.$ alga $\left.^{-1} \mathrm{~d}^{-1}\right)=0.00934 \times(\mathrm{ESD})-0.106, \mathrm{r}^{2}=0.693$. CpC: Cochlodinium polykrikoides fed on a cryptophyte $\times$ GpC: Gonyaulax polygramma on a cryptophyte; HtC: Heterocapsa triquetra on a cryptophyte; PdC: P. donghaiense on a cryptophyte; PmC: P. micans on a cryptophyte; LpP: L. polyedrum on P. minimum; LpS: L. polyedrum on $S$. trochoidea $\mathrm{d}^{-1}$ ) feeding on a cryptophyte under the conditions provided in the present study was much lower than that of C. polykrikoides on the same prey (0.16 ng C grazer $^{-1} \mathrm{~d}^{-1}$ ) despite having a similar ESD. When feeding on cryptophyte cells, the engulfment by P. micans through the suture on the sides of the body may be a less efficient mechanism than that of other mixotrophic dinoflagellates through the sulcus. The time for the cryptophyte cell to be completely engulfed by $P$. micans (629 s) was much longer than that by $C$. polykrikoides (245 s) (Jeong et al. 2004).

\section{Potential grazing impact}

Grazing coefficients attributable to Prorocentrum donghaiense $\left(2.67 \mathrm{~h}^{-1}\right)$, Heterocapsa triquetra $\left(0.091 \mathrm{~h}^{-1}\right)$ and $P$. micans $\left(0.043 \mathrm{~h}^{-1}\right)$ on co-occurring cryptophytes obtained in the present study correspond to the removals of 93.0,9.1, and $4.2 \%$, respectively, of cryptophyte populations by each of $P$. donghaiense, $H$. triquetra, and $P$. micans populations in $1 \mathrm{~h}$. In addition, the grazing coefficients attributable to Lingulodinium polyedrum on co-occurring small Prorocentrum spp. $(P$. minimum $+P$. triestinum $)$ obtained in the present study were up to $0.026 \mathrm{~h}^{-1}$ (i.e. up to $2.6 \%$ of small Prorocentrum spp. populations were removed by a $L$. polyedrum population in $1 \mathrm{~h}$ ), while those on cooccurring Scrippsiella trochoidea were up to $0.011 \mathrm{~h}^{-1}$ (i.e. up to $1.1 \%$ of $S$. trochoidea populations were removed by a $L$. polyedrum population in $1 \mathrm{~h}$ ). The results of the present study suggest that these algal predators may sometimes have a considerable grazing impact on populations of co-occurring prey species. However, the grazing rates of some mixotrophic dinoflagellates are known to be affected by light and/or nutrient conditions (Hansen \& Nielsen 1997, Steocker et al. 1997, Jeong et al. 1999, Hansen et al. 2000, Jakobsen et al. 2000, Li et al. 2000, Skovgaard et al. 2000). Therefore, the grazing impact of algal predators on co-occurring phytoplankton may also be affected by light and/or nutrient conditions. Further, competition among algal predators for common prey species and predator-prey relationships among the algal predators may affect the grazing impact of the algal predators on co-occurring phytoplankton.

\section{Ecological importance}

The feeding by these red-tide dinoflagellates on diverse phytoplankton species may be important in marine planktonic communities in the following ways: (1) there may be broad predator and prey relationships between red-tide dinoflagellates and co-occurring 
diverse phytoplankton species. In particular, the feeding by larger mixotrophic red-tide dinoflagellates on smaller red-tide dinoflagellates may be a driving force for succession of dominant species during serial red tides. For example, in Masan Bay, Korea, from June 21 to July, 6 2004, a bloom dominated by a mixture of Amphidinium sp. and Heterosigma akashiwo were followed by one dominated by a mixture of Prorocentrum minimum and $P$. triestinum, by Cochlodinium polykrikoidea, and then by $P$. micans in series (Fig. 17). In the present study and Jeong et al. (2004) $P$. minimum and $P$. triestinum which were able to feed on Amphidinium carterae and $H$. akashiwo were ingested in turn by C. polykrikoidea and P. micans. (2) There may be severe competition among red-tide

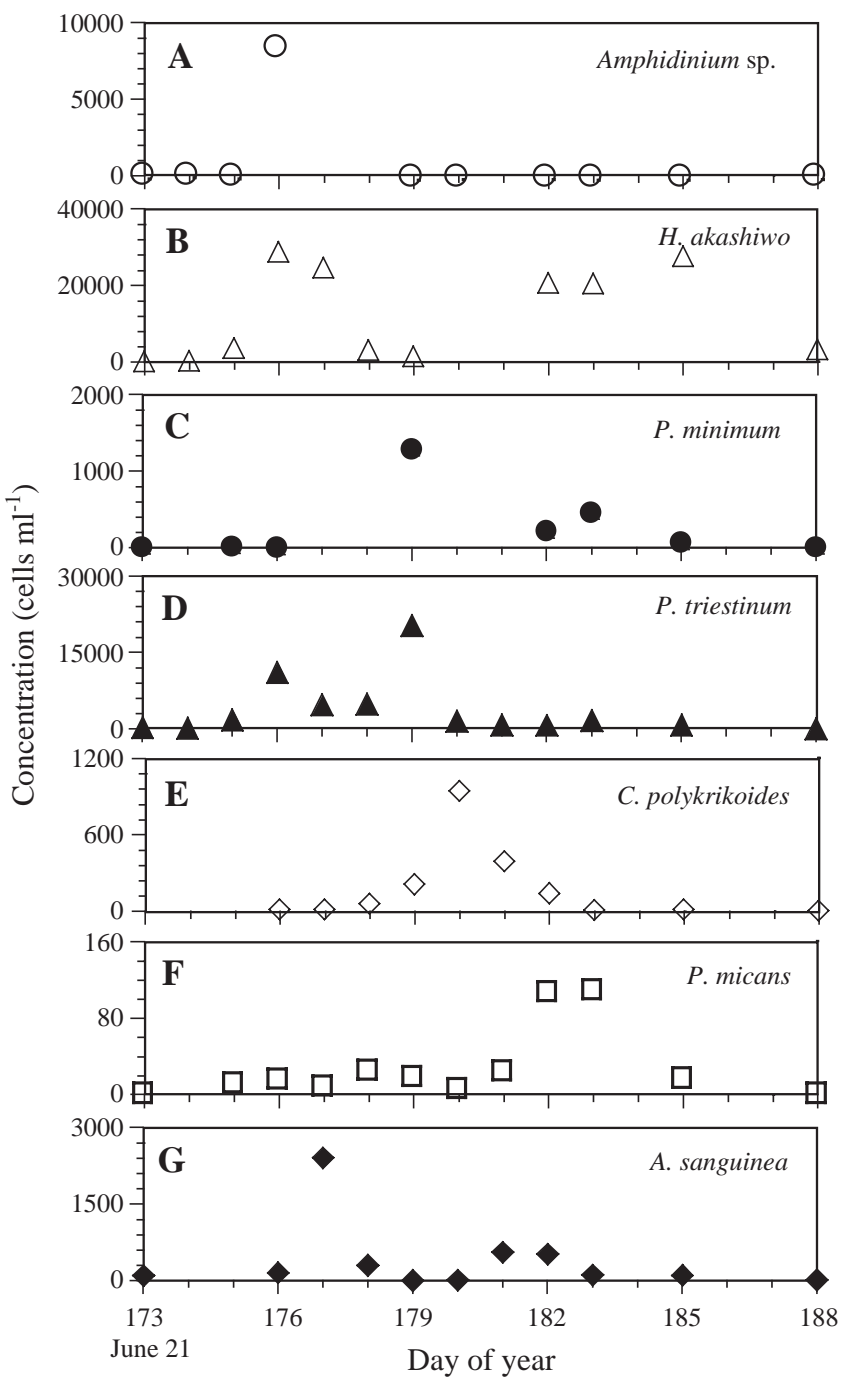

Fig. 17. Abundances of the red-tide organisms (A) Amphidinium sp., (B) Heterosigma akashiwo, (C) Prorocentrum minimum, (D) P. triestinum, (E) Cochlodinium polykrikoides, (F) P. micans, and (G) Akashiwo sanguinea at a pier in Masan Bay, Korea, from June 21 to July 6, 2004 dinoflagellates for common prey species if they cooccur. All algal predators tested in the present study may compete for the phytoplankton species which have ESDs $<12 \mu \mathrm{m}$, and Akashiwo sanguinea and Lingulodinium polyedrum, which are 2 of the most dominant species during the red tides off southern California, USA (Eppley \& Harrison 1975, MoreyGaines 1980, Fiedler 1982, Jeong 1995, Kudela \& Cochlan 2000), may also compete for diverse phytoplankton species including $A$. tamarense, $H$. triquetra, and $S$. trochoidea. (3) There may also be competition between red-tide dinoflagellates and co-occurring heterotrophic protists and metazooplankton for common phytoplankton prey species. For example, the red-tide dinoflagellates which have ESDs $\geq 12.6 \mu \mathrm{m}$ may compete with the heterotrophic dinoflagellates Gyrodinium dominans and G. spirale (Kim \& Jeong 2004), the tintinnid ciliate Favella taraikaensis (Taniguchi \& Kawakami 1985), and the naked ciliate Strombidinopsis sp. (Jeong et al. 1999) for P. minimum. A. sanguinea and $L$. polyedrum may also compete with $F$. ehrenbergii (Stoecker et al. 1981) and Strombidinopsis sp. (Jeong et al. 1999) for $S$. trochoidea. (4) Red-tide dinoflagellates may provide a link between a phytoplankton prey and co-occurring heterotrophic protists and metazooplankton for which phytoplankton is a poor prey item. The heterotrophic dinoflagellates Protoperidinium cf. divergens and Polykrikos kofoidii did not feed or rarely fed on small Prorocentrum spp. ( $P$. minimum and $P$. balticum), while they fed actively on $L$. polyedrum and $S$. trochoidea which actively ingest small Prorocentrum spp. (Jeong \& Latz 1994, Jeong et al. 2001). Therefore, the nutrients of the small Prorocentrum spp. may be transferred to $P$. cf. divergens and $P$. kofoidii via $L$. polyedrum and S. trochoidea. L. polyedrum, which has the widest phytoplankton prey species offered in the present study, is known to be the preferred prey for and/or to support the positive growth of many protozoan and metazoan grazers such as Protoperidinium crassipes (Jeong \& Latz 1994), the mixotrophic dinoflagellate Fragilidium cf. mexicanum (Jeong et al. 1999), F. ehrenbergii (Stoecker et al. 1981), the prostomatid ciliate Tiarina fusus (Jeong et al. 2002), and the calanoid copepods Acartia tonsa and Paracalanus parvus (Morey-Gaines 1980) as well. Therefore, the change in dominant species from less preferred prey species to L. polyedrum during red tides in series may provide more favorable conditions for satiation and population growth of the heterotrophic predators.

Acknowledgements. We thank Nam Seon Kang and Jong Hyeok Kim for technical support. This paper was funded by a grant from the Korean Research Foundation (R02-2004-00010033-0). 


\section{LITERATURE CITED}

Altamirano C, Hernandez-Becerril RDU, Luna-Soria R (1996) Red tides in Mexico: a review. Harmful and toxic algal blooms. Intergovernmental Oceanographic Commission, Paris, p 101-104

Anderson DM, Sulliva JJ, Reguera B (1989) Paralytic shellfish poisoning in northwest Spain: the toxicity of the dinoflagellate Gymnodinium catenatum. Toxicon 27:665-674

Bennouna A, Berland B, El Attar J, Assobhei O (2002) Lingulodinium polyedrum (Stein) Dodge red tide in shellfish areas along Doukkala coast (Moroccan Atlantic). Oceanol Acta 25:159-170

Bockstahler KR, Coats DW (1993) Grazing of the mixotrophic dinoflagellate Gymnodinium sanguineum on ciliate population of Chesapeake Bay. Mar Biol 116:447-487

Bruno M, Gucci PMB, Pierdominici E, Ioppolo A, Volterra L (1990) Presence of saxitoxin in toxic extracts from Gonyaulax polyedra. Toxicon 28:1113-1116

Carlucci AF (1970) Vitamin B12, thiamine, biotin. In: Strickland JDH (ed) The ecology of the phytoplankton off La Jolla, California, in the period April through September, 1967. Bull Scripps Inst Oceanogr 17:23-31

Chang J, Carpenter (1994) Inclusion bodies in several species of Ceratium Schrank (Dinophyceae) from the Caribbean Sea examined with DNA-specific staining. J Plankton Res 16:197-202

ECOHAB (1995) The ecology and oceanography of harmful algal blooms. A national research agenda. Woods Hole Oceanographic Institute, Woods Hole, MA, p 1-66

Eppley RW, Harrison WG (1975) Physiological ecology of Gonyaulax polyedra, a red tide water dinoflagellate of southern California. In: Locicero VR (ed) Proceedings of the 1st International Conference on Toxic Dinoflagellate Blooms. Massachusetts Science and Technology Foundation, Wakefield, MA, p 11-22

Fiedler PC (1982) Zooplankton avoidance and reduced grazing responses to Gymnodinuim splendens (Dinophyceae). Limnol Oceanogr 27:961-965

Frost BW (1972) Effects of size and concentration of food particles on the feeding behavior of the marine planktonic copepod Calanus pacificus. Limnol Oceanogr 17:805-815

Gaines G, Elbrächter M (1987) Heterotrophic nutrition. In: Taylor FJR (ed) The biology of dinoflagellates. Blackwell, Oxford, p 649-722

Glibert PM, Landsberg JH, Evans JJ, Al-Sarawi MA and 6 others (2002) A fish kill of massive proportion in Kuwait Bay, Arabian Gulf, 2001: the roles of bacterial disease, harmful algae, and eutrophication. Harmful Algae 1: 215-231

Granéli E, Anderson DM, Carlsson P, Maestrini SY (1997) Light and dark carbon uptake by Dinophysis species in comparison to other photosynthetic and heterotrophic dinoflagellates. Aquat Microb Ecol 13:177-186

Guillard RRL, Ryther JH (1962) Studies of marine planktonic diatoms. I. Cyclotella nana Hustedt and Detonula confervacea (Cleve) Grun. Can J Microbiol 8:229-239

Hallegraeff GM, Fraga S (1998) Bloom dynamics of the toxic dinoflagellate Gymnodinium catenatum, with emphasis on Tasmanian and Spanish coastal waters. In: Anderson DM, Cembella AD, Hallegraeff GM (eds) Physiological ecology of harmful algal blooms. NATO ASI Series Vol G41. Springer-Verlag, Berlin, p 59-80

Hansen PJ, Calado AJ (1999) Phagotrophic mechanisms and prey selection in free-living dinoflagellates. J Eukaryot Microbiol 46:382-389

Hansen PJ, Nielsen TG (1997) Mixotrophic feeding of Fragi- lidium subglobosum (Dinophyceae) on three species of Ceratium: effects of prey concentration, prey species and light intensity. Mar Ecol Prog Ser 147:187-196

Hansen PJ, Bjornsen PK, Hansen BW (1997) Zooplankton grazing and growth: scaling within the $2-2,000-\mu \mathrm{m}$ body size range. Limnol Oceanogr 42:687-704

Hansen PJ, Skovgaard A, Glud RN, Stoecker DK (2000) Physiology of the mixotrophic dinoflagellate Fragilidium subglobosum. 2. effects of time scale and prey concentration on photosynthetic performance. Mar Ecol Prog Ser 201: $137-146$

Heinbokel JF (1978) Studies on the functional role of tintinnids in the Southern California Bight. I. Grazing and growth rates in laboratory cultures. Mar Biol 47:177-189

Hernandez-Becerril DU, Cortes Altamirano R, Alonso RR (2000) The dinoflagellate genus Prorocentrum along the coasts of the Mexican Pacific. Hydrobiologia 418:111-121

Holmes RW, Williams PM, Eppley RW (1967) Red water in La Jolla Bay, 1964-1966. Limnol Oceanogr 12:503-512

Jacobson DM, Anderson DM (1996). Widespread phagocytosis of ciliates and other protists by marine mixotrophic and heterotrophic thecate dinoflagellates. J Phycol 32:279-285

Jakobsen HH, Hansen PJ, Larsen J (2000) Growth and grazing responses of two chloroplast-retaining dinoflagellates: effect of irradiance and prey species. Mar Ecol Prog Ser 201:121-128

Jeong HJ (1995) The interactions between microzooplanktonic grazers and dinoflagellates causing red tides in the open coastal waters off southern California. PhD thesis, University of California, San Diego, CA

Jeong HJ, Latz MI (1994) Growth and grazing rates of the heterotrophic dinoflagellate Protoperidinium spp. on red tide dinoflagellates. Mar Ecol Prog Ser 106:173-185

Jeong HJ, Lee CW, Yih WH, Kim JS (1997) Fragilidium cf. mexicanum, a thecate mixotrophic dinoflagellate, which is prey for and a predator on co-occurring thecate heterotrophic dinoflagellate Protoperidinium cf. divergens. Mar Ecol Prog Ser 151:299-305

Jeong HJ, Shim JH, Kim JS, Park JY, Lee CW, Lee Y (1999) The feeding by the thecate mixotrophic dinoflagellate Fragilidium cf. mexicanum on red tide and toxic dinoflagellate. Mar Ecol Prog Ser 176:263-277

Jeong HJ, Kim SK, Kim JS, Kim ST, Yoo YD, Yoon JY (2001) Growth and grazing rates of the heterotrophic dinoflagellate Polykrikos kofoidii on red-tide and toxic dinoflagellates. J Eukaryot Microbiol 48:298-308

Jeong HJ, Yoon JY, Kim JS, Yoo YD, Seong K A (2002) Growth and grazing rates of the prostomatid ciliate Tiarina fusus on red-tide and toxic algae. Aquat Microb Ecol 28:289-297

Jeong HJ, Yoo YD, Kim JS, Kim TH, Kim JH, Kang NS, Yih WH (2004) Mixotrophy in the phototrophic harmful alga Cochlodinium polykrikoides (Dinophycean): prey species, the effects of prey concentration and grazing impact. J Eukaryot Microbiol 51:563-569

Jeong HJ, Yoo YD, Seong KA, Kim JH and 5 others (2005) Feeding by the mixotrophic dinoflagellate Gonyaulax polygramma: mechanisms, prey species, the effects of prey concentration, and grazing impact. Aquat Microb Ecol 38:249-257

Kim JS, Jeong HJ (2004) Feeding by the heterotrophic dinoflagellates Gyrodinium dominans and G. spirale on the red-tide dinoflagellate Prorocentrum minimum. Mar Ecol Prog Ser 280:85-94

Kudela RM, Cochlan WP (2000) Nitrogen and carbon uptake kinetics and the influence of irradiance for a red tide bloom off southern California. Aquat Microb Ecol 21:31-47 
Labib W (2000) Dinoflagellate 'Brown Tides' in Alexandria, Egypt waters during 1997-1998. Pakistan. J Mar Sci 9: 33-49

Legović T, Vilicic D, Petricioli D, Zutic V (1991) Subsurface Gonyaulax polyedra bloom in a stratified estuary. Mar Chem 32:361-374

Legrand C, Granéli E, Carlsson P (1998) Induced phagotrophy in the photosynthetic dinoflagellate Heterocapsa triquetra. Aquat Microb Ecol 15:65-75

Lewis J, Hallett R (1997) Lingulodinium polyedrum (Gonyaulax polyedra) a blooming dinoflagellate. Oceanogr Mar Biol Annu Rev 35:97-161

Li A, Stoecker DK, Coats DW (2000) Mixotrophy in Gyrodinium galatheanum (dinophyceae): grazing responses to light intensity and inorganic nutrients. J Phycol 36:33-45

Liu S, Wang WX (2002) Feeding and reproductive responses of marine copepods in South China Sea to toxic and nontoxic phytoplankton. Mar Biol 140:595-603

Lu D, Goeble J, Yuzao Q, Zou J (2002) Prorocentrum donghaiense-a high biomass bloom-forming species in the East China Sea. Harmful Algae News 23:1-4

Lu S, Hodgkiss I (2004) Harmful algal bloom causative collected from Hong Kong waters. Hydrobiologia 512: 231-238

Marasović I (1989) Encystment and excystment of Gonyaulax polyedra during a red tide. Estuar Coast Shelf Sci 28: 35-41

McMinn A, Hallegraeff G, Roberts J, Smith J, Lovell A, Jenkinson A, Heijnis H (2001) Recent introduction of Gymnodinium catenatum to Port Lincoln, South Australia. In: Hallegraff GM, Blackburn SI, Bolch CJ, Lewis RJ (eds) Harmful algal blooms 2000, Intergovernmental Oceanographic Commission of UNSECO, Paris, p 477-480

Morey-Gaines G (1980) The ecological role of dinoflagellate blooms in the Los Angeles-Long Beach Harbor. PhD thesis, University of Southern California, Los Angeles, CA

Nakamura H, Fujimaki K, Sampei O, Murai A (1993) Gonyol: methionine-induced sulfonium accumulation in a dinoflagellate Gonyaulax polyedra. Tetrahed Lett 34:8481-8484

National Fisheries Research and Development Institute (NFRDI) (1998) Red tides in Korea. National Fisheries Research \& Development Institute, Busan

Nygaard K, Tobiesen A (1993) Bacterivory in algae: a survival strategy during nutrient limitation. Limnol Oceanogr 38: 273-279

Editorial responsibility: John Dolan, Villefranche-sur-Mer, France
Qi Y, Wang Y (2003) What the Prorocentrum species should be? - a review on identification of a Prorocentrum species from the East China Sea. Ying Yong Sheng Tai Xue Bao (J Appl Ecol) 14:1188-90 (in Chinese with English abstract)

Schnepf E, Elbrächter M (1992) Nutritional strategies in dinoflagellates: a review with emphasis on cell biological aspects. Eur J Protistol 28:3-24

Skovgaard A (1996) Engulfment of Ceratium spp. (Dinophyceae) by the thecate photosynthetic dinoflagellate Fragilidium subglobosum. Phycologia 35:490-499

Skovgaard A (2000) A phagotrophically derivable growth factor in the plastidic dinoflagellate Gyrodinium resplendens (Dinophyceae). J Phycol 36:1069-1078

Skovgaard A, Hansen PJ, Stoecker DK (2000) Physiology of the mixotrophic dinoflagellate Fragilidium subglobosum. 1. Effects of phagotrophy and irradiance on photosynthesis and carbon content. Mar Ecol Prog Ser 201:129-136

Smalley GW, Coats DW, Adam EJ (1999) A new method using fluorescent microspheres to determine grazing on ciliates by the mixotrophic dinoflagellate Ceratium furca. Aquat Microb Ecol 17:167-179

Stoecker DK (1999) Mixotrophy among dinoflagellates. J Eukaryot Microbiol 46:397-401

Stoecker DK, Guillard RRL, Kavee RM (1981) Selective predation by Favella ehrenbergii (Tintinnida) on and among dinoflagellates. Biol Bull (Woods Hole) 160:136-145

Stoecker DK, Li A, Coats DW, Gustafson DE, Nannen MK (1997) Mixotrophy in the dinoflagellate Prorocentrum minimum. Mar Ecol Prog Ser 152:1-12

Strathmann RR (1967) Estimating the organic carbon content of phytoplankton from cell volume or plasma volume. Limnol Oceanogr 12:411-418

Sweeney BM (1975) Red tides I have known. In: Locicero VR (ed) Proceedings of the 1st International Conference on Toxic Dinoflagellate Blooms. Massachusetts Science and Technology Foundation, Wakefield, MA, p 225-234

Taniguchi A, Kawakami R (1985) Feeding activity of a tintinnid ciliate Favella taraikaensis and its variability observed in laboratory. Mar Microb Food Webs 1:17-34

Yanagi T, Hirao K, Matsuyama Y, Honjo T (1994) Red tide of Gymnodinium mikimotoi at Gokasho Bay. Umi/la merTokyo 32:65-70

Zhu M, Li R, Mu X, Ji R (1997) Harmful algal blooms in China Seas. Ocean Res 19:173-184

Submitted: February 8, 2005; Accepted: April 25, 2005

Proofs received from author(s): July 23, 2005 